\title{
The community composition variation of Russulaceae associated with the Quercus mongolica forest during the growing season at Wudalianchi City, China
}

\author{
Pengjie Xing ${ }^{\text {Equal first author, } 1}$, Yang Xu ${ }^{\text {Equal first author, } 1}$, Tingting Gao ${ }^{1}$, Guanlin Li ${ }^{1}$, Jijiang Zhou ${ }^{1}$, Mengle Xie $^{1,2}$, Ruiqing Ji \\ Corresp. 1 \\ ${ }^{1}$ Engineering Research Center of Edible and Medicinal Fungi, Jilin Agricultural University, Changchun, China \\ 2 \\ 2 Life Science College, Northeast Normal University, Changchun, China \\ Corresponding Author: Ruiqing Ji \\ Email address: jiruiqingjrq@126.com
}

Background. Most species of the Russulaceae are ectomycorrhizal (ECM) fungi, which are widely distributed in different types of forest ecology and drive important ecological and economic functions. Little is known about the composition variation of the Russulaceae fungal community aboveground and in the root and soil during the growing season (June-October) from a Quercus mongolica forest. In this study, we investigated the changes in the composition of the Russulaceae during the growing season of this type of forest in Wudalianchi City, China.

Methods. To achieve this, the Sanger sequencing method was used to identify the Russulaceae aboveground, and the high-throughput sequencing method was used to analyze the species composition of the Russulaceae in the root and soil. Moreover, we used the Pearson correlation analysis, the redundancy analysis and the multivariate linear regression analysis to analyze which factors significantly affected the composition and distribution of the Russulaceae fungal community.

Results. A total of 56 species of Russulaceae were detected in the Q. mongolica forest, which included 48 species of Russula, seven species of Lactarius, and one species of Lactifluus. Russula was the dominant group. During the growing season, the sporocarps of Russula appeared earlier than those of Lactarius. The number of species aboveground exhibited a decrease after the increase and were significantly affected by the average monthly air temperature $(r=-0.822, p=0.045)$, average monthly relative humidity $(r=-0.826, p=0.043)$, monthly rainfall $(r=0.850, p=0.032)$, soil moisture $(r=0.841$, $p=0.036)$ and soil organic matter $(r=0.911, p=0.012)$. In the roots and soils under the $Q$. mongolica forest, the number of species did not show an apparent trend. The number of species from the roots was the largest in September and the lowest in August, while those from the soils were the largest in October and the lowest in June. Both were significantly affected by the average monthly air temperature $\left(r^{2}=\right.$ $0.6083, p=0.040)$ and monthly rainfall $\left(r^{2}=0.6354, p=0.039\right)$. Moreover, the relative abundance of Russula and Lactarius in the roots and soils showed a linear correlation with the relative abundance of the other fungal genera. 
1 The community composition variation of Russulaceae associated with the Quercus mongolica

2 forest during the growing season at Wudalianchi City, China

3 Pengjie Xing ${ }^{1}$, Yang Xu ${ }^{1}$, Tingting Gao ${ }^{1}$, Guanlin Li ${ }^{1}$, Jijiang Zhou ${ }^{1}$, Mengle Xie ${ }^{1,2}$, Ruiqing $4 \mathrm{Ji}^{1 *}$

$5{ }^{1}$ Engineering Research Center of Edible and Medicinal Fungi, Jilin Agricultural University,

6 Changchun, China

$7 \quad{ }^{2}$ Life Science College, Northeast Normal University, Changchun, China

$8{ }^{*}$ Corresponding Author:

$9 \quad$ Ruiqing Ji

10 Xincheng Street 2888, Changchun, China

11 jiruiqingjrq@126.com

12 Abstract

Background. Most species of the Russulaceae are ectomycorrhizal (ECM) fungi, which are widely distributed in different types of forest ecology and drive important ecological and economic functions. Little is known about the composition variation of the Russulaceae fungal community aboveground and in the root and soil during the growing season (June-October) from a Quercus mongolica forest. In this study, we investigated the changes in the composition of the Russulaceae during the growing season of this type of forest in Wudalianchi City, China.

Methods. To achieve this, the Sanger sequencing method was used to identify the Russulaceae aboveground, and the high-throughput sequencing method was used to analyze the species composition of the Russulaceae in the root and soil. Moreover, we used the Pearson correlation analysis, the redundancy analysis and the multivariate linear regression analysis to analyze which factors significantly affected the composition and distribution of the Russulaceae fungal community.

Results. A total of 56 species of Russulaceae were detected in the Q. mongolica forest, which included 48 species of Russula, seven species of Lactarius, and one species of Lactifluus. Russula 
was the dominant group. During the growing season, the sporocarps of Russula appeared earlier than those of Lactarius. The number of species aboveground exhibited a decrease after the increase and were significantly affected by the average monthly air temperature $(r=-0.822, p=0.045)$, average monthly relative humidity $(r=-0.826, p=0.043)$, monthly rainfall $(r=0.850, p=0.032)$, soil moisture $(r=0.841, p=0.036)$ and soil organic matter $(r=0.911, p=0.012)$. In the roots and soils under the $Q$. mongolica forest, the number of species did not show an apparent trend. The number of species from the roots was the largest in September and the lowest in August, while those from the soils were the largest in October and the lowest in June. Both were significantly affected by the average monthly air temperature $\left(r^{2}=0.6083, p=0.040\right)$ and monthly rainfall $\left(r^{2}\right.$ $=0.6354, p=0.039)$. Moreover, the relative abundance of Russula and Lactarius in the roots and soils showed a linear correlation with the relative abundance of the other fungal genera.

\section{Introduction}

Almost all the land plant species form a mutualistic symbiosis with mycorrhizal fungi, including endo- and ectomycorrhizal (ECM) fungi. ECM fungi can favor the nutrient uptake of the host, promote plant growth and enhance plant drought resistance and disease resistance (Bryla and Duniway 1997; Brundrett and Kendric 1998; Harley and Smith 2008; Smith and Read 2008; Courty et al. 2010; Dickie 2015; Lofgren et al. 2018; Pacé et al. 2018), and at the same time, complete their life histories through the absorption of essential nutrients from the soil and the roots of the host (Karwa et al. 2011). On a global scale, the ECM fungi have a rich diversity and an extensive distribution. These ECM fungi play an essential role for host trees and contribute to the proper functioning of forest ecosystems. The composition of the ECM fungal community has received much attention from researchers.

The community composition of ectomycorrhizal fungi in forest ecosystems shows monthly changes. Previous research showed that he ECM community species richness in the Quercus ilex L. roots was the highest in the autumn and the lowest in the summer (Román and Miguel 2005). The ECM root tip abundance changed with the season variation (Blasius et al. 1990). The peak productivity of the Russulaceae fungi in the C. cuspidata forest was in mid-summer (Murakami 1987). Moreover, the composition and distribution of the ECM fungal community have been influenced by biotic factors and abiotic factors. 
In biotic factors, the ECM fungi not only interact with their host (Kernaghan et al. 2003; Izzo et al. 2005; Vasco-Palacios et al. 2018) but also with other soil fungi, including other ECM, saprotrophic and pathogenic fungi (Cairney and Meharg 2002; Kennedy 2010; Mundra et al. 2016). Abiotic factors in the climate and soil have strong effects on the ECM fungal community. Warming could increase the abundance of the ECM fungi in the roots (Deslippe et al. 2011; Saravesi et al. 2019). Abundant rainfall and soil moisture are necessary for the fungi to fruit. If the soil moisture potential was too low, the fungi were unable to obtain sufficient water for fruit body development (Salerni et al. 2002; Barroetaveña et al. 2008). The soil pH was also the primary factor affecting the evenness of the belowground mycorrhizal communities (Suz et al. 2014). Additionally, the complementarity of P uptake was affected by the diversity of the ECM fungal species, and P uptake efficiency is related to soil moisture; the efficiency of the P uptake decreased when the soil moisture was limiting (Köhler et al. 2018). Long-term $\mathrm{N}$ deposition in the soil can lead to a decline in the richness in the ECM fungal species and dramatic changes in the ECM fungal community structure (Lilleskov et al. 2002; Hedwall et al. 2018).

Most of the research on the ECM fungal community microecology described above was based solely on samples from aboveground or belowground (Villarreal-Ruiz and Neri-Luna, 2018). However, there are some contradictions on the ECM community between the aboveground and belowground, while some common fruiting species produced few mycorrhizae; some common species observed on the roots were poorly represented or entirely lacking in the aboveground fruiting record (Gardes and Bruns 1996). Therefore, it is necessary to study the ECM fungal community combining the aboveground and belowground species (Dickie et al. 2009; Wei et al. 2018).

Almost all of the species of the Russulaceae are ECM fungi and are widely distributed in temperate regions. They can be associated with species of pine, oak, fir, and spruce (Bills et al. 1986; Kernaghan et al. 1997; ADAMČÍK et al. 2013; Wang et al. 2015; Lazarević and Menkis 2017; Wang et al. 2017).

Q. mongolica Fisch. ex Ledeb. is one of the quickest growing, high-yield plantation tree species and comprises the primary commercial forests in Northeast China. The symbiotic relationship between the Russulaceae fungi and $Q$. mongolica plays an important role in maintaining the regional ecological balance and enabling ecosystem restoration and reconstruction. Currently, 
87

most researchers have focused on the composition of the Russulaceae community in oak forests. The Russulaceae fungi are dominant in the oak forests of North America (Dickie et al. 2009) and the $Q$. mongolica forest of Inner Mongolia China (Wei et al. 2018) from both the aboveground and belowground. However, the components of the microecology of the Russulaceae fungal community in the $Q$. mongolica forest are unclear and merit further study.

In our study, based on the investigation of the Russulaceae fungal community from aboveground and belowground in different months during the growing season from June to October, we aimed to study: (1) what the trends of the changes in the community composition of the Russulaceae fungi are during the growth season in the Q. mongolica forest, and (2) how abiotic factors and biotic factors affect the community composition of the Russulaceae fungi. We hypothesized that (1) during the growing season, the species number of Russulaceae fungi aboveground would increase first and then decrease; the species number of Russulaceae fungi in roots would remain basically unchanged, and the species number of Russulaceae fungi in soils would increase; (2) temperature and soil $\mathrm{pH}$ were important factors affecting the composition and distribution of the Russulaceae fungi aboveground and belowground; (3) fungi sporocarp diversity (including Russulaceae) on the above-ground and in the root system mostly was influenced by the soil fungal community.

\section{Materials and method}

\section{Study site}

Our study site, the $Q$. mongolica forest, is located at the Jiaodebu forest farm construction area, Wudalianchi Scenic Area nature reserve, Heilongjiang Province, China (126 $16^{\prime} 0 \mathrm{E}, 48^{\circ} 37^{\prime} 0 \mathrm{~N}$, $303 \mathrm{~m}$ asl) (our researchs has been allowed), which is almost covered by volcanic ash soil, and is a temperate continental monsoon climate with an average temperature of $0^{\circ} \mathrm{C}$. The area receives approximately 600-900 mm rainfall per year with peaks during June-August.

\section{Sampling strategy}

Four $20 \mathrm{~m} \times 20 \mathrm{~m}$ plots were surveyed, with an interval of over $200 \mathrm{~m}$ between plots at the site, which is composed of Q. mongolica (98\%) and Betula platyphylla Sukaczev (2\%). We collected samples twice per month from June 2018 to October 2018. 
115

116

117

118

119

120

121

122

123

124

125

126

127

128

129

130

131

132

133

134

135

136

137

138

139

The sporocarps of the Russulaceae fungi were randomly acquired and fully counted in each plot. Sporocarps were photographed in the field using a Canon EOS 70D digital camera. Fresh morphological characters were recorded, and the colors were designated using the Munsell Color System (Jabeen et al. 2016). Some sporocarps of each species were selected and contained in zip lock bags with silica gel, while the others were dried by an oven (approximately $50^{\circ} \mathrm{C}$ ) and placed into specimen boxes.

The root samples were collected using a five-point sampling method, i.e., five sampling points were distributed in the middle and four corners of the plot, respectively. In each point, we randomly selected a target tree, collected the fine root segments (approximately $15-30 \mathrm{~cm} \mathrm{long}$ ) in four directions of $1 \mathrm{~m}$ from the trunk of the tree (Wang et al. 2017) (Figure 1). Simultaneously, a soil sample was also collected using the five-point sampling method (Figure 1). Eight cylinders of soil were collected randomly from each point (approximately $12 \mathrm{~cm}$ deep and $5 \mathrm{~cm}$ in diameter) to remove the impurities and then mixed (more than $500 \mathrm{~g}$ ) together (Castaño et al. 2016). All the root and soil samples from the five points during the same month were homogenized, respectively, and pooled to obtain a composite sample, which was placed into a cooler containing ice and transported to our laboratory.

\section{Sample processing}

We identified the Russulaceae fungal sporocarps based on morphological observation and molecular identification methods. Anatomical features were measured using a Zeiss Lab. A1 microscope. For detailed anatomical examination, tissues from the specimens were mounted on glass slides and observed in Phloxine (1\%) for better contrast and Melzer's KOH (5\%) for colored hyphae. We measured basidia ( $n=10 /$ sample) and basidiospores $(n=20 /$ sample) as length range $\times$ width range (Jabeen et al. 2016).

The DNA of the sporocarps was extracted using a CTAB method (Gardes and Bruns 1993). A polymerase chain reaction (PCR) with the primer pairs ITS-1F and ITS-4 or ITS4-B (White et al. 1990; Gardes and Bruns 1993) was conducted, and finally the PCR products were sequenced using the Sanger method. The sequences we obtained were BLASTed against the NCBI database and UNITE database at a $98 \%$ sequence identity threshold, and undescribed species were identified to the genus. Sequences generated in this study were submitted to GenBank. 
144

145

146

147

148

149

150

151

152

153

154

155

156

157

158

159

160

161

162

163

164

165

166

167

168

169

170

171

172

173

Each root sample was soaked in Tween 20 (0.1\% in water) for approximately $1 \mathrm{~h}$ and was washed well under running water to remove adhering soil particles. They were then dried completely by placement in a container filled with silica beads. The dried roots were placed in new bags and crumbled to break off the fine roots of the higher order roots. The powdered fine root material were placed into a sterile $50 \mathrm{ml}$ centrifuge tube for DNA extraction (Benucci and Bonito 2016) and high-throughput sequencing.

DNA was extracted from the root sample using a Soil Isolation Kit (MachereyNagel, Germany). The ITS1 region was amplified with primers (ITS1: GTTGGTCATTTAGAGGAAGTAA; ITS2: GCTGCGTTCTTCATCGATGC) using the manufacturer's instructions. The PCR was conducted in $50 \mu \mathrm{L}$ reactions consisting of $30 \mathrm{ng}$ genomic DNA, $4 \mu \mathrm{L}$ PCR Primers, $25 \mu \mathrm{L}$ PCR Master Mix, and $\mathrm{ddH}_{2} \mathrm{O}$ as needed. The PCR reactions were run under the following conditions: $98^{\circ} \mathrm{C}$ for $3 \mathrm{~min}$, followed by thirty cycles of $98^{\circ} \mathrm{C}$ for $45 \mathrm{~s}, 55^{\circ} \mathrm{C}$ for $45 \mathrm{~s}, 72^{\circ} \mathrm{C}$ for $45 \mathrm{~s}$, and a final extension step at $72^{\circ} \mathrm{C}$ for $7 \mathrm{~min}$ before storage at $4^{\circ} \mathrm{C}$. The PCR products were purified with Ampure XPbeads (Agencourt Biosciences, USA) to remove the unspecific products. The samples were then pooled in equimolar concentrations for paired-end sequencing on an Illumina Hi-Seq 2500 platform in BGI Co., Ltd, Beijing, China.

The aluminum box with $20.0 \mathrm{~g}$ of fresh soil obtained with a $2 \mathrm{~mm}$ sieve in an oven at $105^{\circ} \mathrm{C}$ was dried to a constant weight to measure the soil moisture (SM). Some soil was completely dried by placement in a container filled with silica beads for days. The dried soil stone particles that had been removed with the $2 \mathrm{~mm}$ sieve were used for measuring other soil parameters. The soil available phosphorus (P) was determined using $0.5 \mathrm{~mol} \cdot \mathrm{L}^{-1}$ of the $\mathrm{NaHCO}_{3}$ extractionmolybdenum anti-colorimetric method. The soil organic matter (SOM) was detected using the potassium dichromate volumetric method. The soil effective nitrogen $(\mathrm{N})$ was measured by the alkali diffusion method. The soil available potassium $(\mathrm{K})$ was determined using $1 \mathrm{~mol} \cdot \mathrm{L}^{-1}$ $\mathrm{NH}_{4} \mathrm{OAc}$ extraction-flame photometry (Bao 2000). The soil pH was measured by potentiometry.

Some fresh soil samples were placed into a sterile $50 \mathrm{ml}$ centrifuge tube for DNA extraction and high-throughput sequencing. The DNA extraction methods, PCR and sequencing conditions were conducted with the root samples in the same manner as the soil analyses.

\section{Bioinformatics}


174

175

176

177

178

179

180

181

182

183

184

185

186

187

188

189

190

191

192

193

194

195

196

197

198

199

200

201

202

The raw data were filtered to eliminate the adapter pollution and low quality to obtain clean reads. After that, the paired-end reads with overlap were merged to tags. The tags were clustered to operational taxonomic units (OTUs) using USEARCH (v 7.0.1090) (Edgar 2013) at 97\% sequence similarity. OTU representative sequences were taxonomically classified using Ribosomal Database Project RDP Classifier (v. 2.2) trained on the database UNITE (v. 6) using 0.5 confidence values. At last, the alpha diversity was analyzed based on the OTU and taxonomic ranks. The high-throughput sequencing raw data of fungus in root and soil samples were uploaded into Sequence Read Archive (SRA) in NCBI (SRA accession: SRR10590054 - SRR10590058, SRR10590043 - SRR10590047).

\section{Statistical Analyses}

Three alpha diversity indices were used to analyze the community composition of the Russulaceae fungi aboveground. The Menhinick richness index (D1) reflected the species richness of the community. The Shannon index (D2) reflected the diversity of the community species. The Pielou's evenness index (D3) reflected the evenness of the distribution of the number of individuals in each species. The diversity index formulas were as follows:

$\mathrm{D} 1=\mathrm{S} / \sqrt{ }(\mathrm{N}), \mathrm{S}$ is the total number of species in the community; $\mathrm{N}$ is the total number of individuals observed;

$\mathrm{D} 2=-\sum P_{i} \operatorname{Ln}\left(P_{i}\right), P_{i}$ is the proportion of individuals found belonging to the $i$ th species; $\ln$ is the natural logarithm;

$$
\text { D3= H'/H' } \max , H^{\prime} \max =\operatorname{Ln}(S), H^{\prime}=D^{\prime} \text {. }
$$

The alpha diversity index (i.e., the Chao and Shannon indices) in the root and soil samples were calculated using Mothur (v 1.31.2). A one-way analysis of variance (ANOVA) was performed on the alpha diversity index difference of the sporocarps aboveground and the Russulaceae fungi in the root and soil from different months, respectively, and was conducted to analyze the difference of the Shannon index between the aboveground and roots and between the aboveground and soil, respectively, in July and August, with Tukey's HSD test at $P<0.05$ in SPSS (v 19.0). The Wilcoxon Rank-Sum test was used to compare the differences in the alpha diversity index between the root and soil groups, and then a plotbox of the alpha diversity drawn by R. and Linear Discriminant Analysis (LDA) was used to examine the significant difference in the Russulaceae species via 
203

204

205

206

207

208

209

210

211

212

213

214

215

216

217

218

219

220

221

222

223

224

225

226

227

228

229

230

Lefse software. A Venn diagram was used to visualize the shared number of Russulaceae species between above- and belowground.

Abiotic factors were stated and included the monthly rainfall (MR), average month relative humidity (RH), average month air temperature (Temp), SM, SOM, P, N, K, and $\mathrm{pH}$. The data for the MR, RH and Temp were obtained from the Dazhanhe Meteorological Station in Wudalianchi City, Heilongjiang Province, China.

The Pearson correlation was utilized to follow the relationship between the alpha diversity index of the Russulaceae sporocarps against these abiotic factors ( $p$-values, two-tailed; confidence intervals, 95\%) using SPSS software. In addition, the redundancy analysis (RDA) was used to analyze the correlation between the Russulaceae fungal community composition of the belowground and these variables using the R package Vegan (v 2.0-10).

The multivariate linear regression analysis in SPSS was used to detect the relative abundance correlation of other genera with Russula and Lactarius in the root and soil, respectively. We assigned OTUs to the functional groups using the online application FUNGuild ("http: // www. stbates. Org/ guilds/ app. php") (Nguyen et al. 2016). Only FUNGuild assignments at the confidence level of 'highly probable' and 'probable' were used for the analysis.

\section{Results}

The composition variation on the growing seasonal basis of the Russulaceae fungal community on aboveground

The fruiting period of the Russulaceae sporocarps aboveground took place in July and August. A total of 106 sporocarps of the Russulaceae were collected and were classified as 24 different species by morphology and Sanger sequence methods, which included 19 species of Russula, 4 species of Lactarius and 1 species of Lactifluus (Table 1).

The ANOVA analysis indicated that the Menhinick index was the highest in August, significantly higher than that in June, July, September and October, and there was no significant difference between these months. The Shannon index was the highest in August, significantly higher than the other months, and July was also significantly higher than June, September and 
231 October, with no significant difference between these three months. Pielou's evenness index in 232 July was significantly higher than that in June, August, September and October, and there was no 233 significant difference between that in June, September and October (Table 2).

234 The species number of Russulaceae found aboveground during the growing season showed a 235 trend of increasing first and then decreasing. Species of Russula appeared from early July, and 236 reached their numerical peak in the middle of August, gradually decreased at the end of August, 237 and there were almost no sporocarps of Russula in early September. The species of Lactarius 238 appeared at the end of August and reached their numerical peak in the end of August. In September, 239 its numbers quickly decreased. There was only one species of Lactarius in September, and no 240 sporocarps in October. The species of Lactifluus only appeared in late August, while there were 241 no species in September and October (Figure 2a).

242

243

244

245

\section{The composition changes on the growing seasonal basis of the Russulaceae fungal community} from the roots

A total of 1440 OTUs were detected from the root samples, 149 OTUs were unidentified fungi, and 1,291 OTUs were identified fungi, belonging to 4 phyla, 18 classes, 56 orders, 112 families, and 271 genera, of which 40 OTUs were identified to the Russulaceae, accounting for $2.77 \%$ of the entire fungal community, and they were clustered into 37 species, including 30 species of Russula, 6 species of Lactarius, and 1 species of Lactifluus (Table 1).

The Chao richness index of the Russulaceae in August had reached its peak, followed by September, and was the lowest in July, June and October. The Shannon diversity index in June, July and October indicated that their degree of diversity was all significantly higher than that in August and September, but there were no significant differences between August and September (Table 3).

The number of Russulaceae species in the root samples during the growing season, showed a trend of decreasing, then increasing, and then decreasing, and the variation in the number of the species of Russula and Lactarius was basically the same. The number of species of Russula was the largest in September, followed by June, October and July, and the lowest in August. The number of species of Lactarius was the same and the largest in June, September and October, followed by July and August. The species of Lactifluus appeared only in June, August and 
260

261

262

263

264

265

266

267

268

269

270

271

272

273

274

275

276

277

278

279

280

281

282

283

284

285

286

287

288

September, and the number was the same (Figure $2 b$ ).

\section{The composition changes on the growing seasonal basis of the Russulaceae fungal community} from the soils

A total of 1,388 OTUs were detected from the soil samples, 205 OTUs were unidentified fungi, and 1,183 OTUs were identified fungi, belonging to 4 phyla, 18 classes, 52 orders, 106 families, and 245 genera, of which 46 OTUs were identified as members of the Russulaceae, comprising $3.31 \%$ of the entire fungal community, and they were clustered into 42 species, including 37 species of Russula, 4 species of Lactarius, and 1 species of Lactifluus (Table 1).

The Chao richness index of the Russulaceae showed that the richness was the largest in July, and the lowest richness in October, June was similar with August and September. The estimated Shannon diversity index indicated that the degree of diversity was significantly higher in June and August than that in July, September and October, but there were no significant differences between June and August, among July, September and October (Table 3).

The number of species of Russulaceae in the soil samples during the growing season first increased, decreased, and then increased, while the species number variation of Russula and Lactarius were basically the same. The number of Russula species was the largest in October, followed by July, September and August, and June was the lowest. The number of Lactarius was the largest in July and October, followed by June and September, and the lowest in August. The species of Lactifluus appeared in all months except September, and the number of species was the same (Figure 2c).

A comparison of the composition of the Russulaceae fungal community in the roots and soils indicated that there were 34 species of Russulaceae shared between the roots and soils; 3 species were unique in the roots, and 7 species were unique in the soils (Figure 3). The Chao index ( $p=$ $0.0740>0.05)$ and Shannon index $(p=0.5476>0.05)$ of the Russulaceae between the roots and soils showed that there were no significant differences (Figure 4). However, the abundances of some species differed significantly, the abundance of $R$. cyanoxantha, $R$. pallidospora, $R$. foetens and $R$. azurea was significantly lower in the roots than in the soils, while the abundance of $R$. persicina was significantly higher in the roots than in the soils (Figure 5).

\section{Comparing the composition of the Russulaceae fungal community among the aboveground,}


289

290

291

292

293

294

295

296

297

298

299

300

301

302

303

304

305

306

307

308

309

310

311

312

313

314

315

316

317

318

\section{roots and soils}

There were 56 species of Russulaceae detected in the Q. mongolica forest, including 48 species of Russula, 7 species of Lactarius, and 1 species of Lactifluus, among which Russula was the dominant group (Table 1). The difference in the Shannon diversity index for the Russulaceae between the aboveground and roots and the aboveground and soils in July and August was analyzed by an ANOVA, respectively, which showed there were significant differences between the aboveground and roots $(p=0.048<0.05)$ and the aboveground and soil $(p=0.001<0.05)$ in July. In August, there was a significant difference between the aboveground and roots $(p=0.000$ $<0.05)$, but no significant difference with the soils $(p=1.000>0.05)$ (Table 4).

In June, there were no species on the aboveground; 18 species shared between the roots and soils; 5 species were unique in the roots; and 8 species were unique in the soils (Figure 6a). In July, there were 2 species shared between the aboveground, roots and soils; 1 species only shared between the aboveground and soils; 14 species only shared between the roots and soils; 8 species were unique on the aboveground; 2 species were unique in the roots; and 12 species were unique in the soils (Figure 6b). In August, there were 6 species shared between the aboveground, roots and soils; 1 species were only shared between the aboveground and roots; 9 were only shared between the species in the roots and soils; 11 species were unique on the aboveground; and 10 species were unique in the soils (Figure 6c). In September, there was 1 species on the aboveground; 21 species were shared between the roots and soils; 3 species were unique in the roots, and 6 species were unique in the soils (Figure 6d). In October, there were 22 species shared between the roots and soils; 1 species was unique in the roots, and 8 species were unique in the soils (Figure $6 e)$.

\section{Assessing the effects of abiotic factors on the Russulaceae fungal community composition}

Varied results were revealed by the Pearson correlation between the alpha diversity index of the aboveground sporocarps in the $Q$. mongolica forest and nine abiotic factors. The Menhinick richness index showed a significantly negative correlation between the Temp $(r=-0.822, p=$ $0.045)$ and $\mathrm{RH}(r=-0.826, p=0.043)$, and a significantly positive correlation between the SOM $(r=0.911, p=0.012)$ and $\mathrm{SM}(r=0.841, p=0.036)$. The Shannon diversity index had a significantly positive correlation with the $\mathrm{MR}(r=0.850, p=0.032)$ (Table 5$)$. The RDA conducted for the Russulaceae fungal species belowground showed two significantly positive correlation 
319

variables: Temp $\left(r^{2}=0.6083, p=0.040\right)$ and $\mathrm{MR}\left(r^{2}=0.6354, p=0.039\right)$. Other factors, including $\mathrm{RH}, \mathrm{SM}, \mathrm{P}, \mathrm{SOM}, \mathrm{K}, \mathrm{N}$ and $\mathrm{pH}$, had no significant influence on the distribution and diversity of the Russulaceae fungi in the roots and soils (Figure 7a, b).

\section{Other fungal groups correlated with the composition of the Russulaceae fungal community}

By performing a multivariate linear regression analysis in SPSS, we found that the relative abundance of three genera $(R=1, p=0.000)$ in the root was linearly correlated with the relative abundance of Russula, and the linear regression equation was Y1 $=2.058+0.153 \mathrm{U} 1-0.450 \mathrm{U} 2$ +4.609U3 (Y1: Russula, U1: Cortinarius, U2: Exophiala, U3: Herpotrichia). The relative abundances of the three genera $(R=1, p=0.000)$ were linearly correlated with Lactarius, and the equation was $\mathrm{Z} 1=-0.014+0.169 \mathrm{~V} 1+0.008 \mathrm{~V} 2-0.003 \mathrm{~V} 3(\mathrm{Z} 1$ : Lactarius, V1: Inocybe, V2: Nectria, V3: Dictyochaeta).

In the soil, three genera $(R=1, p=0.001)$ correlated with Russula, and the equation was Y2= -0.871 +116.99W1 +22.826W2 +0.38W3 (Y2: Russula, W1: Lachnum, W2: Ilyonectria, W3: Cadophora). Three genera $(R=1, p=0.001)$ correlated with Lactarius, of which the regression equation was Z2 = $0.145+0.901 X 1-0.003 X 2+0.084 X 3$ (Z2: Lactarius, X1: Preussia, X2: Cortinarius, X3:Herpotrichia) (Table 6).

\section{Discussion}

\section{The composition changes on the growing seasonal basis of the Russulaceae fungal community} on the aboveground, roots and soils

Sporocarps on the aboveground were identified using morphological and the Sanger sequencing method, and the species of Russulaceae in the roots and soils in a $Q$. mongolica forest were identified using the high-throughput sequencing method. Although the high-throughput sequencing removed the species of low relative abundance, more comprehensive data was still available. We were able to obtain a more detailed understanding about the community composition of Russualaceae than that provided by the traditional methods, which only rely on the morphological and molecular identification of the mycorrhizae belowground. To avoid the mismatch between the collected time and the ECM formation period of the ECM fungal species in 
347 the forest ecosystems, we collected samples twice per month during the growing season.

348 In this study, we found that the variation trend of the species number of the Russulaceae 349 aboveground was consistent with our previous hypothesis, the period of production of the 350 sporocarps on the aboveground was in July and August. The species number of Russula in a 351 Castanopsis cuspidata (Thunb.) Schottky forest in Japan formed a large peak on July 24, and the number was the lowest after mid-August (Murakami 1987). R. nigricans in Korea was commonly

353

354

355

356

357

358

359

360

361

362

363

364

365

366

367

368

369

370

371

372

373

374

375

376 found during the summer and fall (Park et al. 2014). While the variation trend of the species number of Russulaceae in the roots was not consistent with our previous hypothesis, the species number was the highest in September. The richness of the ECM fungal species in the root of $Q$. ilex was the highest in the fall (September-November) (Román and Miguel 2005), which was similar to our results. Most of the ECM species (Russula, 1\%; Lactarius, 0.3\%; and Amanita, $0.05 \%$ ) in the soil of a Q. petraea (Matt.) Liebl. forest in the Czech Republic had a lower relative abundance in the spring, which was higher in the summer (Russula, 7\%; Lactarius, 6\%; and Amanita, 3.4\%) (Vóísková et al. 2014; Castaño et al. 2017). The diversity and richness of the Russulaceae species in the soil of the $Q$. mongolica forest in our study was higher in the summer than in the autumn.

Some species only presented aboveground and were absent in the roots and soils in the $Q$. mongolica forest, such as R. atroglauca, R. aurata, R. delica and L. evosmus, among others, which are ECM fungi. The reason that these species were absent from the root and soil may be that their trimmed reads had less than $75 \%$ of their original length in the data processing and resulted in their removal. It could also be that the ECM fungi aboveground could transport their spores over long distances to other places through the wind, resulting in species migration (Roy et al. 2008; Hirose et al. 2010; Vellend 2010; Vincenot et al. 2012; Sheedy et al. 2015; Boeraeve et al. 2018; Koizumi et al. 2018). Thus, we could not exclude this possibility. Other species, such as L. pyrogalus, $R$. cyanoxantha, and so on, only presented in the roots and soils, no sporocarps formed on the aboveground, which may be owing to environmental conditions that were not suitable for the formation of the sporocarps.

\section{Assessing the effects of abiotic factors on the Russulaceae fungal community composition}

The composition of the Russulaceae fungal community in the Q. mongolica was driven by the climate and soil. The composition of Russulaceae aboveground was significantly affected by the 
377 Temp, MR, RH, SM and SOM, which were consistent with our hypothesis that Temp and MR

378 were the important factors affecting the composition and distribution of the Russulaceae fungi

379 aboveground. The abundance of ECM fungi in a Mediterranean forest during the same month was

380 dependent primarily on the temperature, high temperatures limited the growth of the ECM fungi

381 at the beginning of the fruiting season but tended to enhance it towards the end (Karavani et al.

382 2018). Rainfall affected the abundance of ECM fungi by affecting soil moisture; therefore, suitable

383 rainfall and soil moisture can promote the abundance of the ECM fungi (Salerni et al. 2002; Ogaya

384 and Peñuelas 2005). In addition, the composition of the Russulaceae fungal community in the roots

385 and soils was also significantly affected by Temp and MR, which were consistent with our

386 hypothesis. Warming increased the abundance of the ECM fungi in the roots of pine forests

387 (Saravesi et al. 2019) and increased the mycelial biomass of L. vinosus (Quél.) Bataille in soil at

388 the Natural Park of Poblet (Castaño et al. 2017). In addition, enough rainfall can promote the 389 growth of ECM fungi in the root of the dry dipterocarp forest (Disyatat et al. 2016).

390 Furthermore, from our survey, we also roughly summarized the range of nine abiotic factors, 391 which were suitable for the growth of the Russulaceae fungal sporocarps. The range of nine abiotic 392 factors in the fruiting period from July to August is found in Table 7 and includes the MR (145.40 $393 \mathrm{~mm}-251.60 \mathrm{~mm}), \mathrm{RH}(86.00 \%-87.00 \%)$, Temp $\left(17.30^{\circ} \mathrm{C}-20.80^{\circ} \mathrm{C}\right), \mathrm{pH}(6.05-6.14), \mathrm{SM}$ 394 (57.08\% - 61.61\%), pH (6.13 - 6.14), N (321.35 mg $\left.\mathrm{kg}^{-1}-321.67 \mathrm{mg} \cdot \mathrm{kg}^{-1}\right), \mathrm{K}\left(523.10 \mathrm{mg} \cdot \mathrm{kg}^{-1}\right.$ $\left.395610.58 \mathrm{mg} \cdot \mathrm{kg}^{-1}\right)$, SOM (15.69\% - 17.67\%) and P ( $\left.32.32 \mathrm{mg} \cdot \mathrm{kg}^{-1}-34.90 \mathrm{mg} \cdot \mathrm{kg}^{-1}\right)$, respectively 396 (Table 7). We hope that these results will provide data to enhance research on the cultivation of 397 mycorrhizal mushrooms.

Correlations of other functional fungi that play an important role in the roots and soils with Russulaceae fungal community composition

400

401

402

403

404

405

406

We used a multiple regression analysis to establish the multiple regression analytical models to analyze the influence of other fungal species on the Russulaceae fungal community composition, which could negate the influence of a third genus when the relationship of two genera with each other was measured. Moreover, we obtained the most suitable equation model by comparing the goodness of fit, correlation coefficient and significance level, which showed that the multiple regression analysis model was more appropriate.

The relative abundance of Russula in the roots was linearly correlated with the relative 
407 abundance of Cortinarius, which co-appeared with Russula in many different forest roots (Jang 408 and Kim 2012; LeDuc et al.. 2013). The relative abundance of Russula in the soils was linearly 409 correlated with the relative abundance of Lachnum, which also appeared in soil of a Lithocarpus 410 densiflorus forest in northern California (Bergemann and Garblelotto 2006). However, there is no 411 evidence to show their relationship, and it is not clear in what manner these genera affect the 412 Russulaceae fungi and merits further study.

\section{Conclusions}

414 This study revealed the composition variation of the Russulaceae fungal community 415 aboveground and in the roots and soils during the growing season of a Quercus mongolica forest. 416 The composition of the Russulaceae fungi had been significantly affected by the average month 417 air temperature, monthly rainfall, average month relative humidity, soil organic matter and soil 418 moisture. This will provide a scientific basis for the further cultivation of the Russulaceae fungi. 419 However, it is not clear in what manner some other genera affect the Russulaceae fungi, and this 420 possibility merits further study.

\section{Acknowledgements}

422

This research was supported by the National Natural Science Foundation of China (No. 31600020) and the Overseas Expertise Introduction Project for Discipline Innovation (111 center) (No. D17014). The work was primarily performed in the Engineering Research Center of Edible and Medicinal Fungi in Jilin Agricultural University for Jilin Province.

\section{References}

Adamčík S, Jančovičová S, Valachovič M. 2013. Russulaceae (Russulales, Agaricomycotina, fungi) in the thermophilous oak forests of W Slovakia. Scripta Botanica Belgica. 51, 64-76.

Bao SD. 2000. Soil agrochemical analysis. Beijing: China Agricultural Press.

Barroetaveña C, La Manna L, Alonso MV. 2008. Variables affecting Suillus luteus fructification in ponderosa pine plantations of Patagonia (Argentina). Forest Ecology and Management, 256(11), 1868-1874. https://doi.org/10.1016/j.foreco.2008.07.029.

Benucci GMN, Bonito GM. 2016. The truffle microbiome: species and geography effects on bac 
434

435

436

437

438

439

440

441

442

443

teria associated with fruiting bodies of hypogeous Pezizales. Microbial ecology. 72(1), 4-8. doi:10.1007/s00248-016-0755-3.

Bergemann SE, Garbelotto M. 2006. High diversity of fungi recovered from the roots of mature tanoak (Lithocarpus densiflorus) in northern California. Botany. 84(9), 1380-1394. https://doi.org/10.1139/b06-097.

Bills GF, Holtzman GI, Miller OK. 1986. Comparison of ectomycorrhizal-basidiomycete communities in red spruce versus northern hardwood forests of west virginia. Botany. 64(4), 760-768. https://doi.org/10.1139/b86-098.

Blasius D, Kottke I, Oberwinkler F. 1990. Spatial and seasonal dynamics of ectomycorrhizae of picea abies (1.) karst. in the black forest. Agriculture Ecosystems \& Environment. 28(1), 27 30. https://doi.org/10.1016/0167-8809(90)90007-Z.

Boeraeve M, Honnay O, Jacquemyn H. 2018. Effects of host species, environmental filtering and forest age on community assembly of ectomycorrhizal fungi in fragmented forests. Fungal ecology. 36: 89-98. https://doi.org/10.1016/j.funeco.2018.08.003.

Brundrett MC, Kendrick B. 1988. The mycorrhizal status, root anatomy, and phenology of plants in a sug. Canadian Journal of Botany. 66(66), 1153-1173. https://doi.org/10.1139/b88-166.

Bryla DR, Duniway JM. 1997. Growth, phosphorus uptake, and water relations of safflower and wheat infected with an arbuscular mycorrhizal fungus. New Phytologist. 136(4), 581590. https://doi.org/10.1046/j.1469-8137.1997.00780.x.

Cairney JW, Meharg

AA. 2002. Interactions between ectomycorrhizal fungi and soil saprotrophs: implications fo $\mathrm{r}$ decomposition of organic matter in soils and degradation of organic pollutants in the rhizo sphere. Canadian Journal of Botany. 80(8), 803-809. https://doi.org/10.1139/b02-072.

Castaño C, Javier P, Pera J, de Aragón JM, Juan Alday JG, Bonet JA. 2016. Soil drying procedure affects the dna quantification oflactarius vinosusbut does not change the fungal community composition. Mycorrhiza. 26(8), 799-808. DOI 10.1007/s00572-016-0714-3.

Castaño C, Alday JG, Parladé J, Pera J, de Aragón JM, Bonet JA. 2017. Seasonal dynamics of the 
461

462

463

464

465

466

467

468

469

470

471

472

473

474

475

476

477

478

479

480

481

482

483

484

485

486

487

ectomycorrhizal fungus Lactarius vinosus are altered by changes in soil moisture and temperature. Soil Biology and Biochemistry. 115, 253-260. https://doi.org/10.1016/j.soilbio.2017.08.021.

Courty PE, Buée M, Diedhiou AG, Frey-Klett P, Tacon FL, Rineau F, Turpault MP, Uroz S, Garbaye J. 2010. The role of ectomycorrhizal communities in forest ecosystem processes: new perspectives and emerging concepts. Soil Biology \& Biochemistry. 42(5), 679-698. https://doi.org/10.1016/j.soilbio.2009.12.006.

Deslippe JR, Hartmann M, Mohn WW, Simard SW. 2011. Long - term experimental manipulation of climate alters the ectomycorrhizal community of Betula nana in Arctic tundra. Global change biology. 17(4), 1625-1636. https://doi.org/10.1111/j.1365-2486.2010.02318.x.

Dickie IA, Dentinger BTM, Avis PG, Mclaughlin DJ, Reich PB. 2009. Ectomycorrhizal fungal communities of oak savanna are distinct from forest communities. Mycologia. 101(4), 473483. https://doi.org/10.3852/08-178.

Dickie IA. 2015. Evolving insights to understanding mycorrhizas. New Phytologist, 205(4), 13691374. doi:10.1111/nph.13290.

Disyatat NR, Yomyart S, Sihanonth P, Piapukiew J. 2016. Community structure and dynamics of ectomycorrhizal fungi in a dipterocarp forest fragment and plantation in Thailand. Plant Ecology \& Diversity. 9(5-6), 577-588. https://doi.org/10.1080/17550874.2016.1264018.

Edgar RC. 2013. UPARSE: highly accurate OTU sequences from microbial amplicon reads. Nat ure methods. 10(10), 996.

Gardes M, Bruns

TD. 1993. ITS primers with enhanced specificity for basidiomycetesapplication to the identification of mycorrhizae and rusts. Molecular ecology. 2(2), 113-118. https://doi.org/10.1111/j.1365-294X.1993.tb00005.x.

Gardes M, Bruns TD. 1996. Community structure of ectomycorrhizal fungi in a Pinus muricata forest: above-and below-ground views. Canadian Journal of Botany, 74(10), 1572-1583. https://doi.org/10.1139/b96-190.

Harley JL, Smith SE, 2008. Mycorrhizal symbiosis. Quarterly Review of Biology. 3(3), 273-281. 
488 Hedwall PO, Gruffman L, Ishida T, From F, Lundmark T, Näsholm T, Nordin A. 2018. Interplay between $\mathrm{n}$-form and $\mathrm{n}$-dose influences ecosystem effects of $\mathrm{n}$ addition to boreal forest. Plant and Soil. 423(1-2), 385-395. https://xs.scihub.ltd/https://doi.org/10.1007/s11104-017-3444-

492 493

494

495

496

497

498

499

500

501

502

503

504

505

506

507

508

509

510

511

512

513 1.

Hirose D, Shirouzu T, Tokumasu S. 2010. Host range and potential distribution of ectomycorrhizal basidiomycete suillus pictus, in japan. Fungal Ecology. 3(3), 255-260. https://doi.org/10.1016/j.funeco.2009.11.001.

Izzo A, Agbowo J, Bruns TD. 2005. Detection of plot-level changes in ectomycorrhizal communities across years in an old - growth mixed conifer forest. New Phytologist. 166(2), 619-630. https://doi.org/10.1111/j.1469-8137.2005.01354.x.

Jabeen S, Niazi AR, Khalid AN. 2016. First record of Russula anthracina and its ectomycorrhiza associated with Himalayan cedar from South Asia. Mycotaxon, 131(1), 31-44. https://doi.org/10.5248/131.31.

Jang SK, Kim SW. 2012. Relationship between higher fungi distribution and climatic factors in Naejangsan National Park. The Korean Journal of Mycology. 40(1), 19-38. https://doi.org/10.4489/KJM.2012.40.1.019.

Karavani A, De Cáceres M, de Aragón JM, Bonet JA, de-Miguel S. 2018. Effect of climatic and soil moisture conditions on mushroom productivity and related ecosystem services in Mediterranean pine stands facing climate change. Agricultural and Forest Meteorology. 248, 432-440. https://doi.org/10.1016/j.agrformet.2017.10.024.

Karwa A, Varma A, Rai M. 2011. Edible ectomycorrhizal fungi: cultivation, conservation and challenges. Diversity and Biotechnology of Ectomycorrhizae. Springer, Berlin, pp. 429-453.

Kennedy P. 2010. Ectomycorrhizal fungi and interspecific competition: species interactions, community structure, coexistence mechanisms, and future research directions. New Phytologist. 187(4), 895-910. https://doi.org/10.1111/j.1469-8137.2010.03399.x.

Kernaghan G, Widden P, Bergeron Y, Légaré S, Paré D. 2003. Biotic and abiotic factors affecting 
514

515

516

517

518

519

520

521

522

523

524

525

526

527

528

529

530

531

532

533

534

535

536

537

538

539

540

ectomycorrhizal diversity in boreal mixed-woods. Oikos. 102(3), 497-504. https://doi.org/10.1034/j.1600-0706.2003.12415.x.

Köhler J, Yang N, Pena R, Raghavan V, Polle A, Meier IC. 2018. Ectomycorrhizal fungal diversity increases phosphorus uptake efficiency of European beech. New Phytologist. 220(4), 12001210. https://doi.org/10.1111/nph.15208.

Koizumi T, Hattori M, Nara K. 2018. Ectomycorrhizal fungal communities in alpine relict forests of Pinus pumila on Mt. Norikura, Japan. Mycorrhiza. 28(2), 129-145. https://xs.scihub.ltd/https://doi.org/10.1007/s00572-017-0817-5.

Lazarević J, Menkis A. 2018. Fungi inhabiting fine roots of Pinus heldreichii in the Montenegrin montane forests. Symbiosis. 74(3), 189-197. https://xs.scihub.ltd/https://doi.org/10.1007/s13199-017-0504-5.

LeDuc SD, Lilleskov EA, Horton TR, Rothstein DE. 2013. Ectomycorrhizal fungal succession coincides with shifts in organic nitrogen availability and canopy closure in post-wildfire jack pine forests. Oecologia. 172(1), 257-269. doi: 10.1007/s00442-012-2471-0.

Lilleskov EA, Fahey TJ, Horton TR, Lovett GM. 2002. Belowground ectomycorrhizal fungal community change over a nitrogen deposition gradient in Alaska. Ecology. 83(1), 104-115. https://doi.org/10.1890/0012-9658(2002)083[0104:BEFCCO]2.0.CO;2.

Lofgren L, Nguyen NH, Kennedy PG. 2018. Ectomycorrhizal host specificity in a changing world: can legacy effects explain anomalous current associations?. New Phytologist. 220(4), 12731284. https://doi.org/10.1111/nph.15008.

Mundra S, Halvorsen R, Kauserud H, Bahram M, Tedersoo L, Elberling B, Eidesen PB. 2016. Ectomycorrhizal and saprotrophic fungi respond differently to long - term experimentally increased snow depth in the High Arctic. MicrobiologyOpen. 5(5), 856-869. https://doi.org/10.1002/mbo3.375.

Murakami Y. 1987. Spatial distribution of Russula species in Castanopsis cuspidata forest. Tran sactions of the British Mycological society. 89(2), 187-193. https://doi.org/10.1016/S0007- 
542

543

544

545

546

547

548

549

550

551

552

553

554

555

556

557

558

559

560

561

562

563

564

565

566

567

568

Nguyen NH, Song Z, Bates ST, Branco S, Tedersoo L, Menke J, Schilling JS, Kennedy PG. 2016. FUNGuild: an open annotation tool for parsing fungal community datasets by ecological guild. Fungal Ecology. 20, 241-248. https://doi.org/10.1016/j.funeco.2015.06.006.

Ogaya R, Peñuelas J. 2005. Decreased mushroom production in a holm oak forest in response to an experimental drought. Forestry. 78(3), 279-283. https://xs.scihub.ltd/https://doi.org/10.1093/forestry/cpi025.

Pacé M, Fenton NJ, Paré D, Stefani FO, Massicotte HB, Tackaberry LE, Bergeron Y. 2019. Lichens Contribute to Open Woodland Stability in the Boreal Forest Through Detrimental Effects on Pine Growth and Root Ectomycorrhizal Development. Ecosystems. 22(1), 189201. doi:10.1007/s10021-018-0262-0.

Park MS, Lee H, Oh SY, Jung PE, Seok SJ, Fong JJ, Lim YW. 2014. Species delimitation of three species within the Russula subgenus Compacta in Korea: R. eccentrica, R. nigricans, and $R$. subnigricans. Journal of Microbiology. 52(8), 631-638. doi:10.1007/s12275-014-4168-z.

Román MD, Miguel AMD. 2005. Post-fire, seasonal and annual dynamics of the ectomycorrhizal community in a Quercus ilex L. forest over a 3-year period. Mycorrhiza. 15(6), 471-482. doi:10.1007/s00572-005-0353-6.

Roy M, Dubois MP, Proffit M, Vincenot

L, Desmarais E, Selosse MA. 2008. Evidence from population genetics that the ectomycorrhizal basidiomycete Lacc aria amethystina is an actual multihost symbiont. Molecular Ecology. 17(12), 2825-283. https://doi.org/10.1111/j.1365-294X.2008.03790.x.

Salerni E, Laganà A, Perini C, Loppi

S, Dominicis VD. 2002. Effects of temperature and rainfall on fruiting of macrofungi in oak forests of the Mediterranean area. Israel Journal of Plant Sciences. 50(3), 189-198.

Saravesi K, Markkola A, Taulavuori E, Syvänperä I, Suominen O, Suokas M, Saikkonen K, Taulavuori K. 2019. Impacts of experimental warming and northern light climate on growth and root fungal communities of Scots pine populations. Fungal Ecology. 40, 1-158. https://doi.org/10.1016/j.funeco.2018.12.010. 
569

570

571

572

573

574

575

576

577

578

579

580

581

582

583

584

585

586

587

588

589

590

591

592

593

594

595

596

Sheedy EM, Van de Wouw

AP, Howlett BJ, May TW. 2015. Population genetic structure of the ectomycorrhizal fungu $\mathrm{s}$ Laccaria sp. A resembles that of its host tree Nothofagus cunninghamii. Fungal ecology. 1 3, 23-32. https://doi.org/10.1016/j.funeco.2014.08.005.

Smith SE, Read DJ. 2008. Mycorrhizal symbiosis. Quarterly Review of Biology. 3(3): 273-281.

Suz LM, Barsoum N, Benham S, Dietrich HP, Fetzer KD, Fischer R, García P, Gehrman J, Kristöfel F, Manninger M, Neagu S, Nicolas M, Oldenburger J, Raspe S, Sánchez G, Schröck HW, Schubert A, Verheyen K, Verstraeten A, Bidartondo MI. 2014. Environmental drivers of ectomycorrhizal communities in Europe's temperate oak forests. Molecular Ecology. 23(22), 5628-5644. https://doi.org/10.1111/mec.12947.

Vasco-Palacios AM, Hernandez J, Peñuela-Mora MC, Franco-Molano AE, Boekhout T. 2018. Ectomycorrhizal fungi diversity in a white sand forest in western Amazonia. Fungal Ecology. 31, 9-18. https://doi.org/10.1016/j.funeco.2017.10.003.

Vellend M. 2010. Conceptual Synthesis in Community Ecology. The Quarterly Review of Biology. 85(2), 183-206. doi:10.1086/652373.

Villarreal-Ruiz L, Neri-Luna C. 2018. Testing sampling effort and relative abundance descriptors of belowground ectomycorrhizal fungi in a UK planted scots pine woodland. Mycology. 9(2), 106-115. https://doi.org/10.1080/21501203.2017.1394393.

Vincenot L, Nara K, Sthultz C, Labbe J, Dubois MP, Tedersoo L, Martin F, Selosse MA. 2012. Extensive gene flow over Europe and possible speciation over Eurasia in the ectomycorrhizal basidiomycete Laccaria amethystina complex. Molecular Ecology. 21(2), 281-299. https://doi.org/10.1111/j.1365-294X.2011.05392.x.

Voříšková J, Brabcová V, Cajthaml T, Baldrian P. 2014. Seasonal dynamics of fungal communities in a temperate oak forest soil. New Phytologist. 201(1), 269-278. https://doi.org/10.1111/nph.12481.

Wang PF, Zhang Y, Mi F, Tang XZ, He XX, Cao Y, Liu CL, Yang D, Dong JY, Zhang KQ, Xu JP. 2015. Recent advances in population genetics of ectomycorrhizal mushrooms Russula spp. Mycology. 6(2), 110-120. https://doi.org/10.1080/21501203.2015.1062810. 
597 Wang X, Liu J, Long D, Han Q, Huang J. 2017. The ectomycorrhizal fungal communities 598 associated with Quercus liaotungensis in different habitats across northern China. 599 Mycorrhiza. 27(5), 441-449. doi: 10.1007/s00572-017-0762-3.

600 Wei J, Yang Y, Hobbie EA, Yan W. 2018. Ectomycorrhizal fungal resources of Inner Mongolia 601 Autonomous Region: above ground macrofungi and belowground ectomycorrhizae. New 602 Forests. 50(4), 521-537. https://xs.scihub.Itd/https://doi.org/10.1007/s11056-018-9691-z.

603

604

605

White TJ, Bruns T, Lee

SJWT, Taylor JL. 1990. Amplification and direct sequencing of fungal ribosomal RNA gen es for phylogenetics. PCR protocols: a guide to methods and applications. 18(1), 315-322. 
Figure 1

The pattern of the five-point method for sampling the roots and soils.

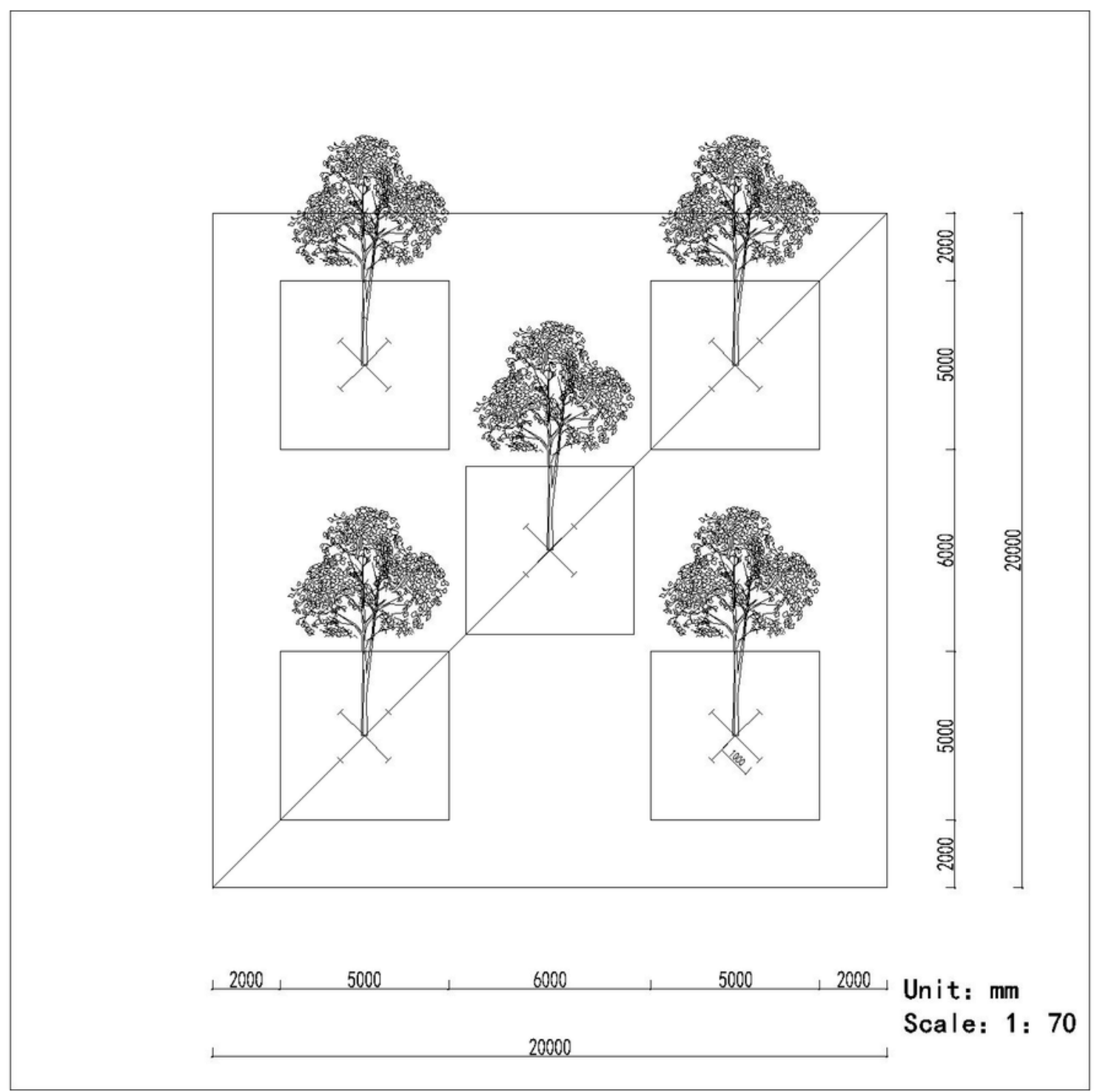


Figure 2

The species number variation of Russula and Lactarius aboveground (a), in the root (b) and soil (c) from five months.
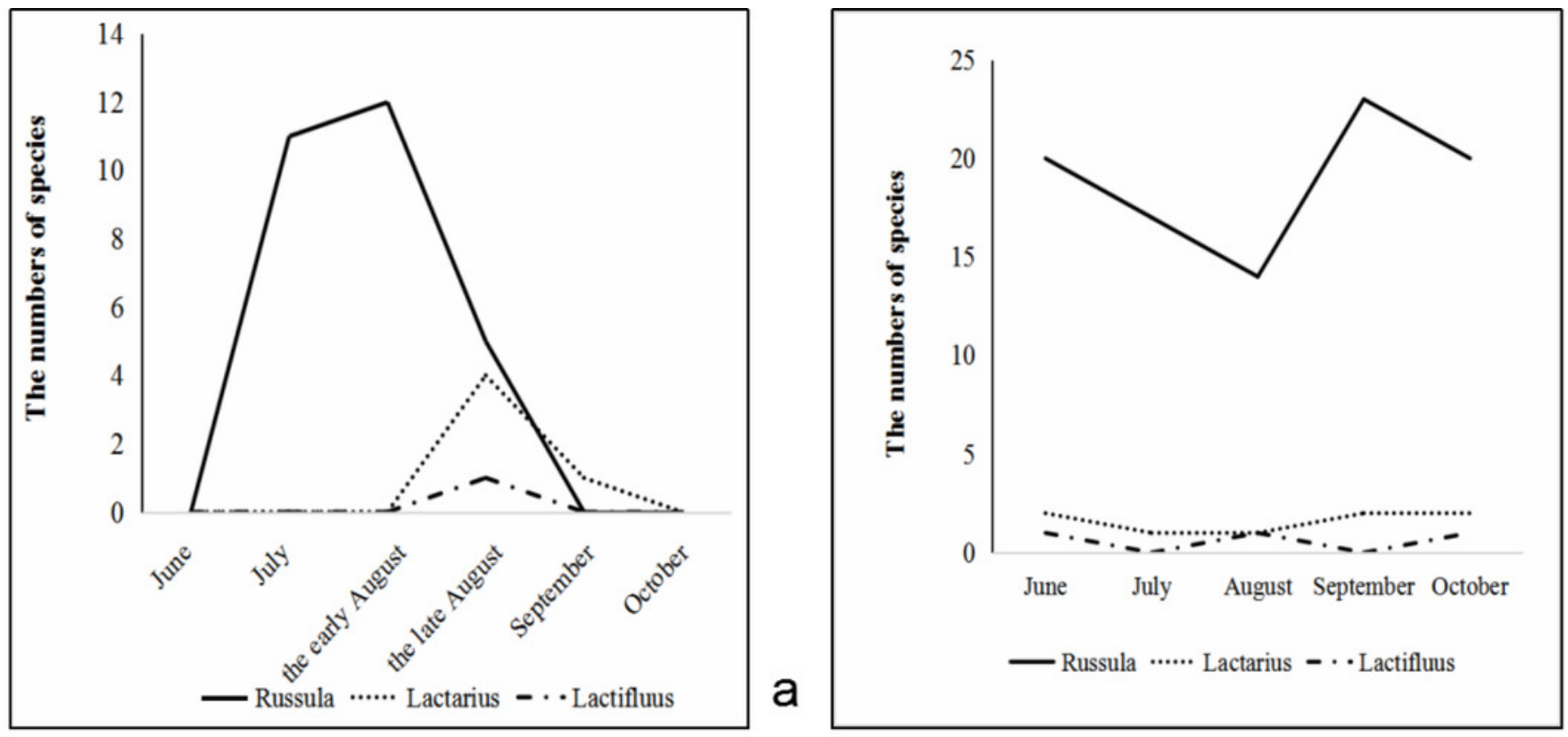

b

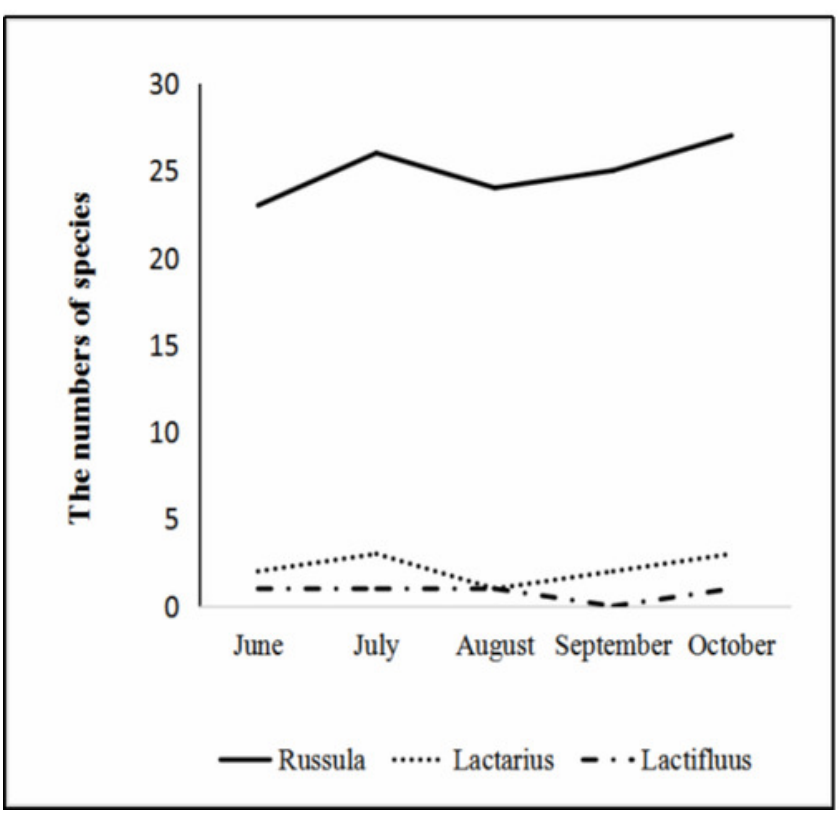

C 


\section{Figure 3}

Venn diagrams showing the number of Russulaceae species shared and unique to the root and soil.

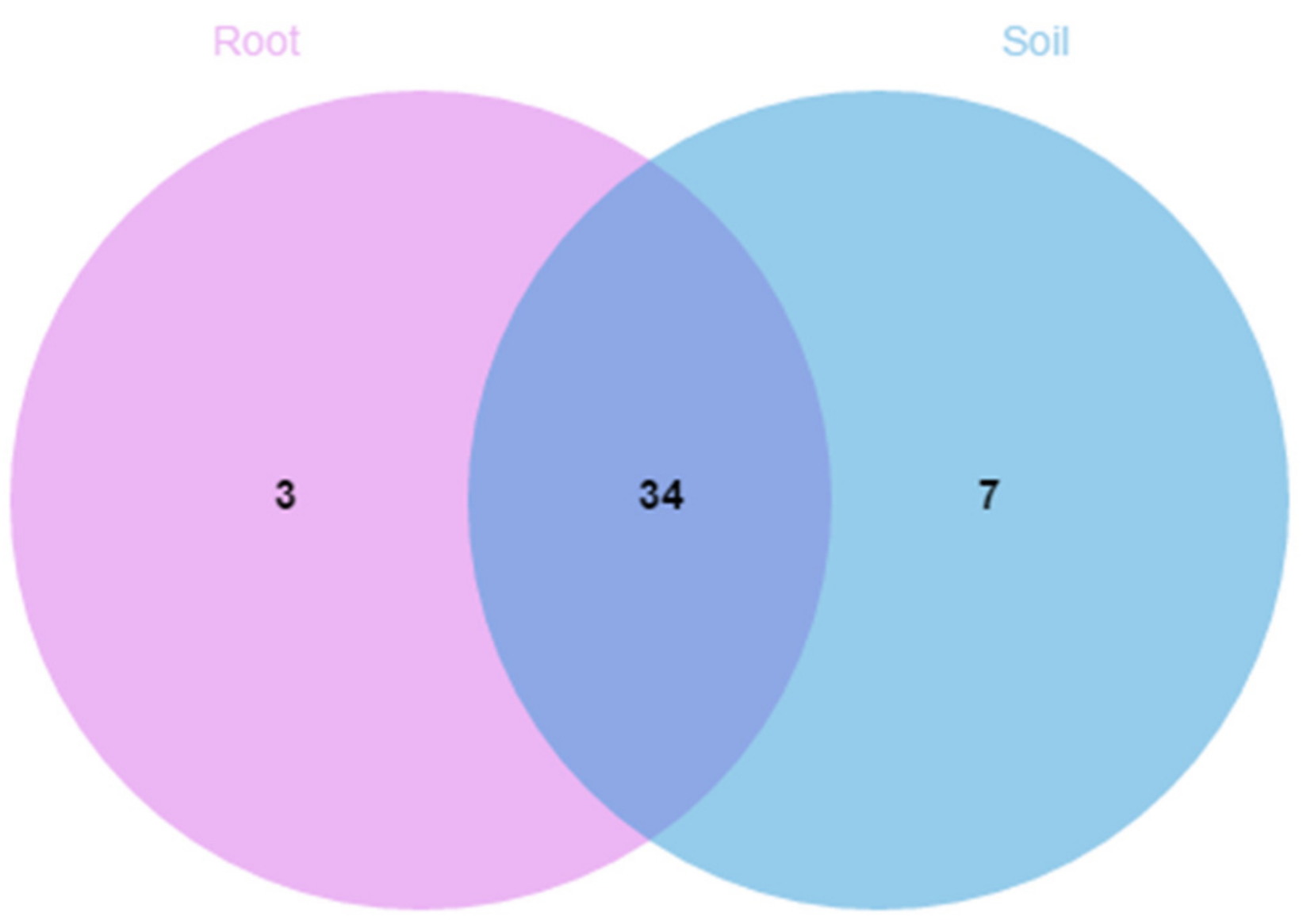


Figure 4

The significant difference of the alpha diversity indices between the root group (R) and the soil group (S) with a confidence interval of $95 \%$. a indicates chao diversity, b indicates shannon diversity.
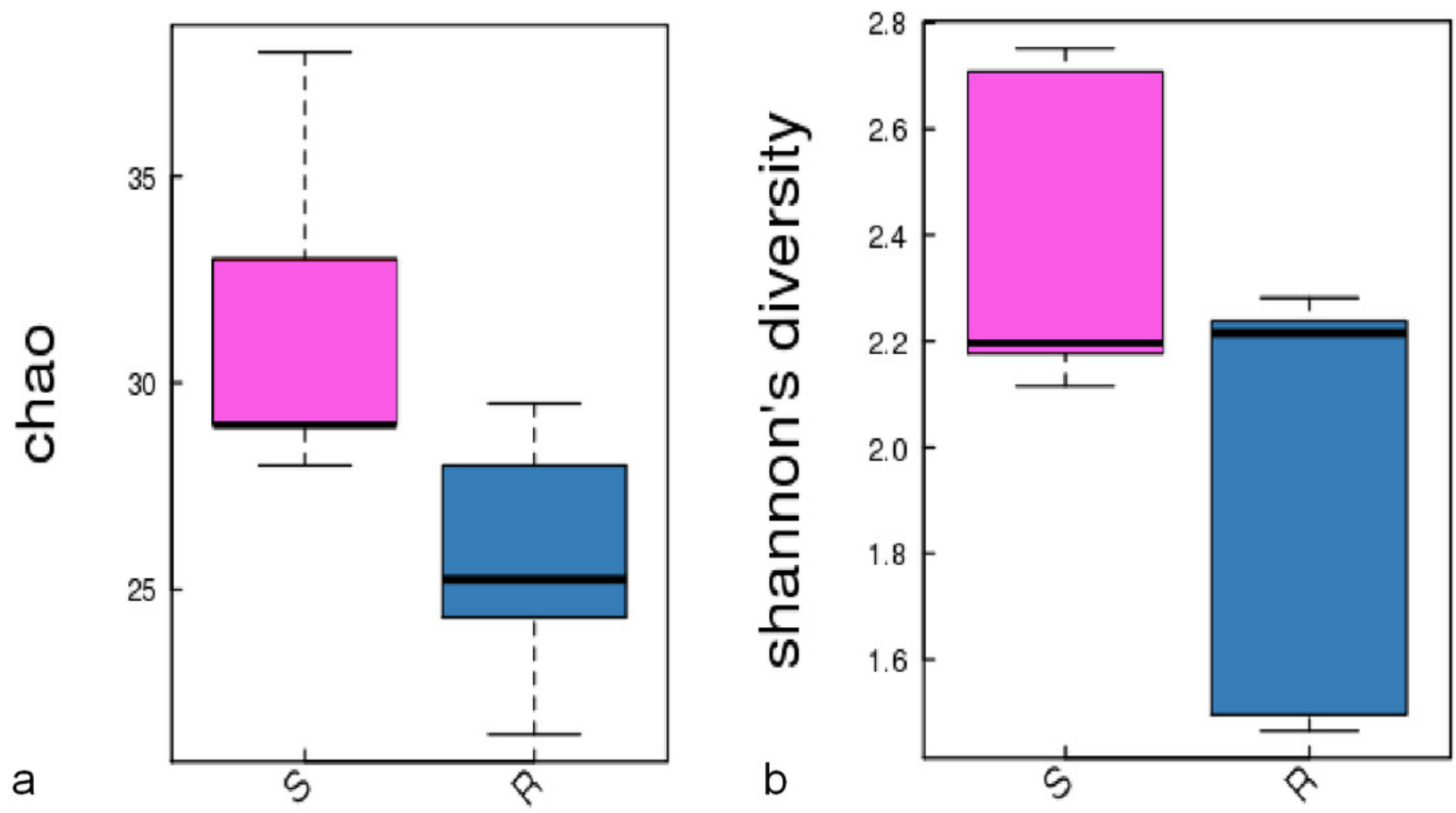
Figure 5

LDA analysis of the root and soil groups. The default score of the LDA is 2.0, and the length of the bar chart represents the influence degree of the LDA score value and the species with significant differences between the different groups.

$\mathrm{R}$ indicates the root group, while $\mathrm{S}$ indicates the soil group.

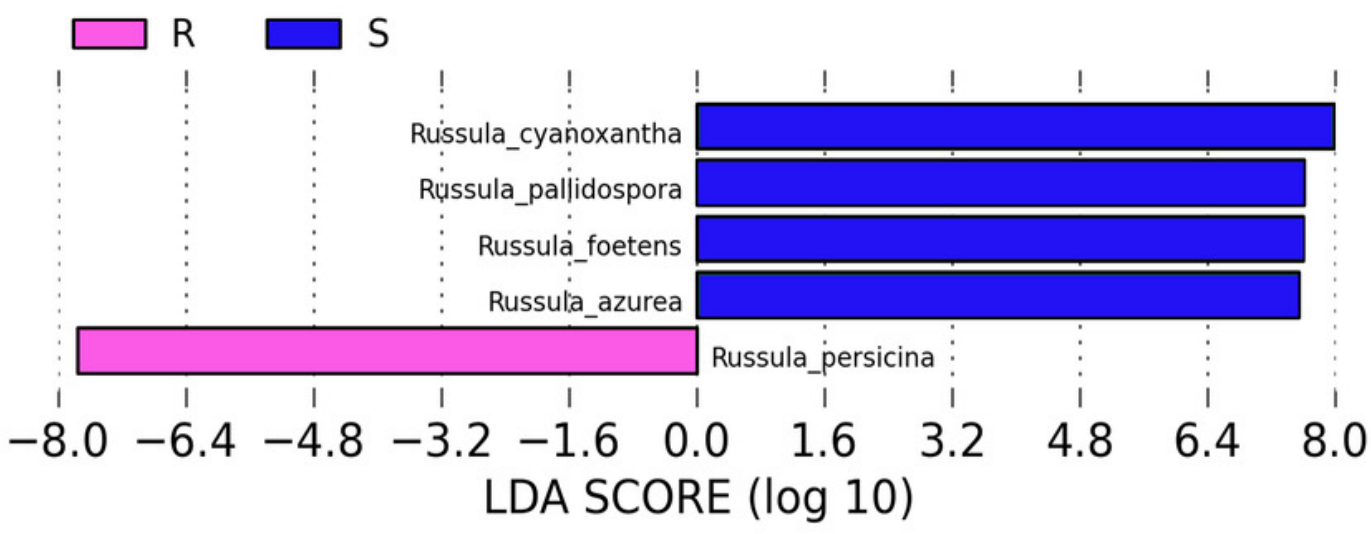


Figure 6

Venn diagrams showing the number of species shared and unique between the aboveground, root and soil from the different months; $a$ indicates June; $b$ indicates July; $c$ indicates August; $d$ indicates September, and e indicates October. 

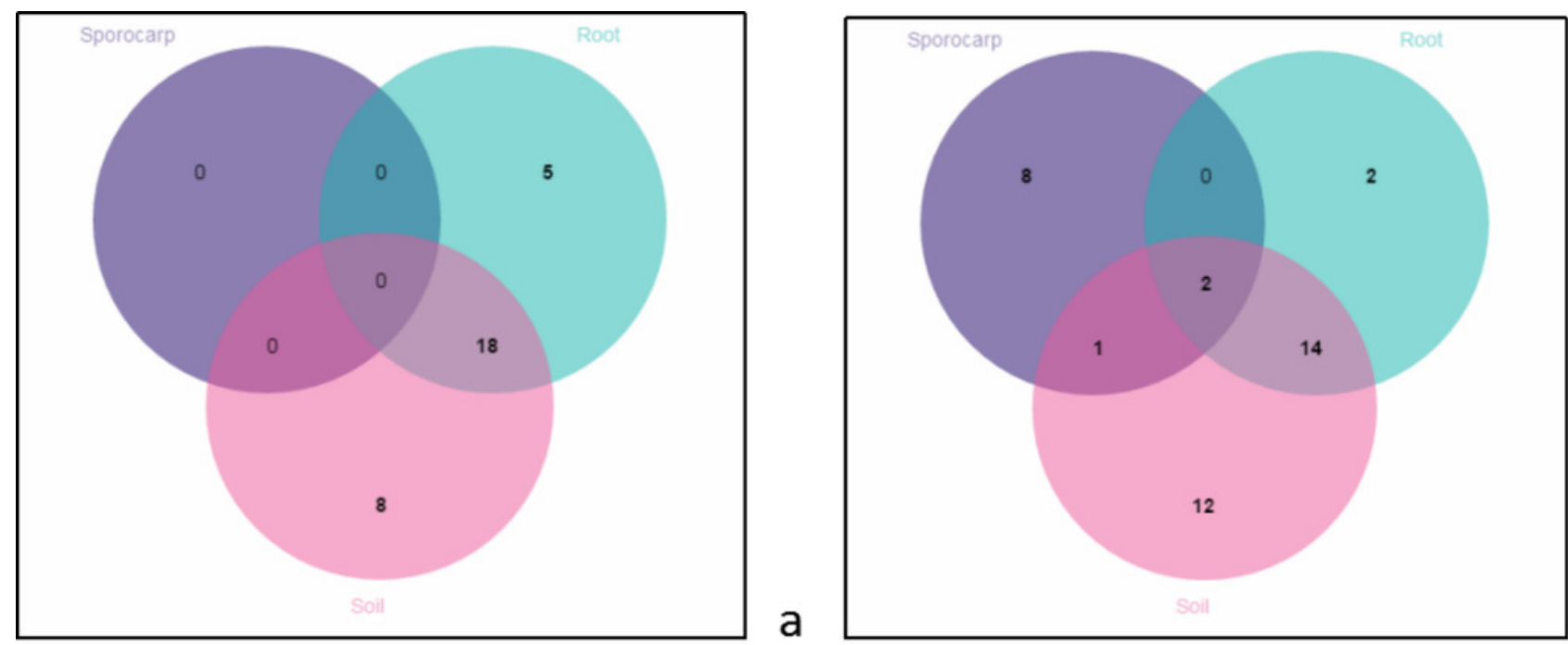

b
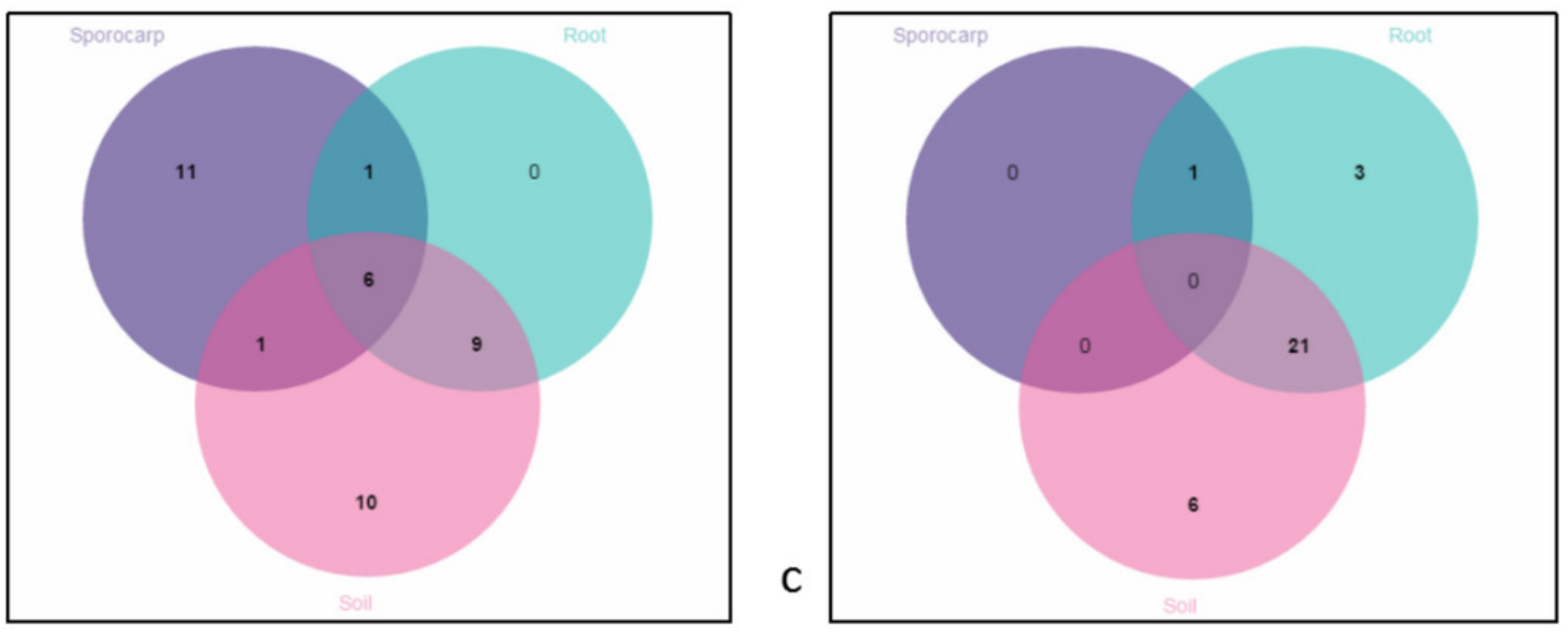

d

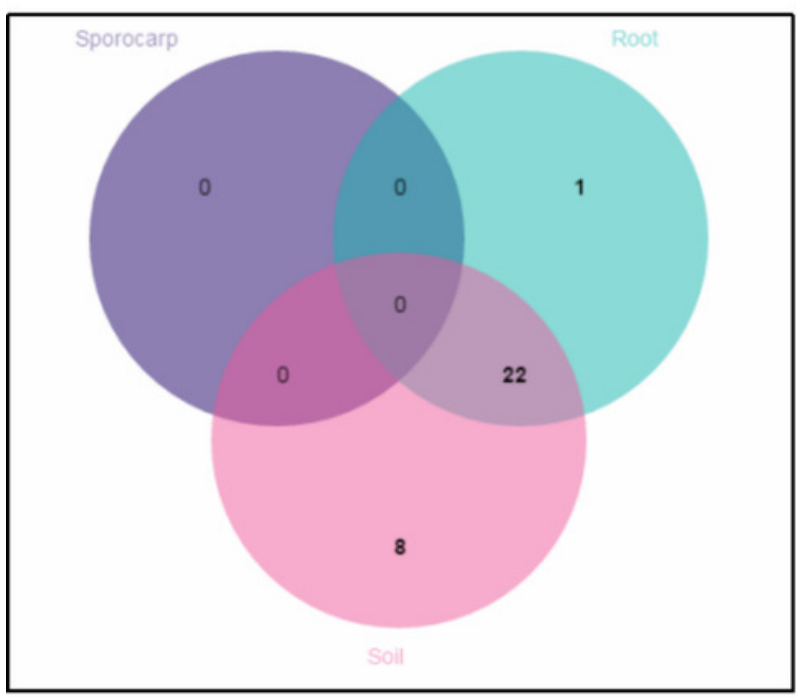

e 
Figure 7

Ordination diagram illustrating the effects of species ( $a$ and b) - Temp, Rain, Air, SM, P, $\mathrm{SOM}, \mathrm{N}, \mathrm{K}$ and $\mathrm{pH}$ based upon an RDA analysis of the belowground Russulaceae fungal communities.

Significance codes: $0.1>\mathrm{P}>0.05 ; * 0.05>\mathrm{P}>0.01 ; * * 0.01>\mathrm{P}>$.

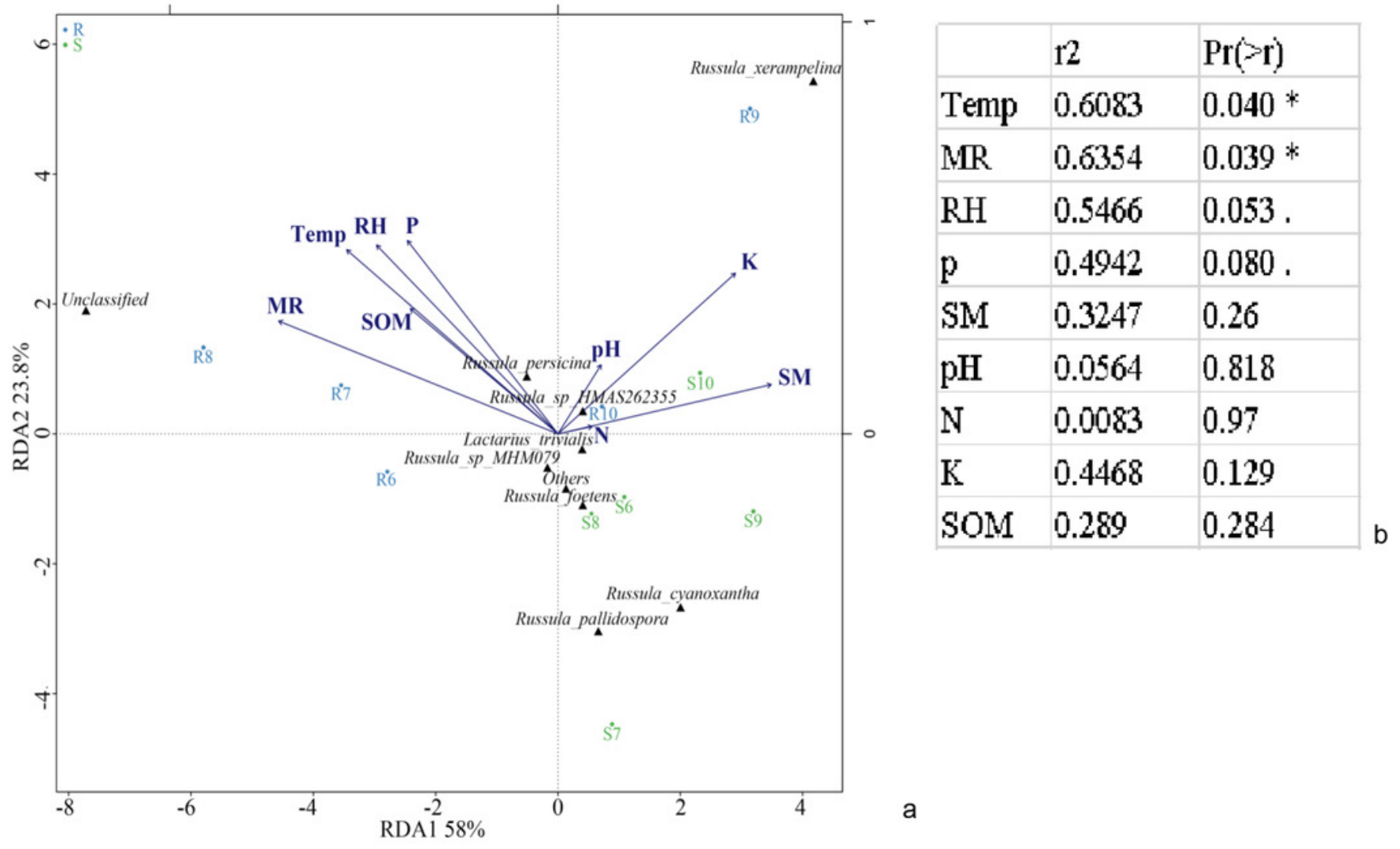




\section{Table 1 (on next page)}

The species of Russulaceae from above-ground, root and soil in different months. 
Table 1

2 The species of Russulaceae from above-ground, root and soil in different months.

\begin{tabular}{|c|c|c|c|c|c|c|c|c|c|c|c|c|c|c|c|}
\hline & & $a b o$ & ve-gro & und & & & & Root & & & & & Soil & & \\
\hline Species name & Jun. & Jul. & Aug. & Sep. & Oct. & Jun. & Jul. & Aug. & Sep. & Oct. & Jun. & Jul. & Aug. & Sep. & Oct. \\
\hline $\begin{array}{l}\text { Lactarius mammosus } \\
\text { Fr. }\end{array}$ & -- & -- & -- & -- & -- & -- & -- & -- & -- & $\sqrt{ }$ & -- & -- & -- & -- & -- \\
\hline $\begin{array}{l}\text { Lactarius pyrogalus } \\
\text { (Bull.) Fr. }\end{array}$ & -- & -- & -- & -- & -- & $\sqrt{ }$ & -- & -- & $\sqrt{ }$ & -- & $\sqrt{ }$ & $\sqrt{ }$ & $\sqrt{ }$ & -- & $\sqrt{ }$ \\
\hline $\begin{array}{l}\text { Lactarius torminosus } \\
\text { (Schaeff.) Gray }\end{array}$ & -- & -- & $\sqrt{ }$ & $\sqrt{ }$ & -- & -- & $\sqrt{ }$ & -- & $\sqrt{ }$ & -- & -- & -- & -- & -- & -- \\
\hline $\begin{array}{l}\text { Lactarius trivialis (Fr.) } \\
\text { Fr. }\end{array}$ & -- & -- & $\sqrt{ }$ & -- & -- & $\sqrt{ }$ & -- & -- & -- & -- & $\sqrt{ }$ & -- & -- & $\sqrt{ }$ & $\sqrt{ }$ \\
\hline $\begin{array}{l}\text { Lactarius vietus (Fr.) } \\
\text { Fr. }\end{array}$ & -- & -- & $\sqrt{ }$ & -- & -- & -- & -- & $\sqrt{ }$ & -- & $\sqrt{ }$ & -- & $\sqrt{ }$ & -- & -- & $\sqrt{ }$ \\
\hline $\begin{array}{l}\text { Lactarius evosmus } \\
\text { Kühner \& Romagn. }\end{array}$ & -- & -- & $\sqrt{ }$ & -- & -- & -- & -- & -- & -- & -- & -- & -- & -- & -- & -- \\
\hline Lactarius $s p$ & - & -- & - & -- & -- & $\sqrt{ }$ & - & -- & - & - & - & $\sqrt{ }$ & - & $\sqrt{ }$ & -- \\
\hline $\begin{array}{l}\text { Lactifluus bertillonii } \\
\text { (Neuhoff ex Z. } \\
\text { Schaef.) Verbeken }\end{array}$ & -- & -- & $\sqrt{ }$ & -- & -- & -- & -- & $\sqrt{ }$ & -- & $\sqrt{ }$ & $\sqrt{ }$ & $\sqrt{ }$ & $\sqrt{ }$ & -- & $\sqrt{ }$ \\
\hline $\begin{array}{l}\text { Russula anthracina } \\
\text { Romagn. }\end{array}$ & -- & -- & -- & -- & -- & $\sqrt{ }$ & $\sqrt{ }$ & $\sqrt{ }$ & $\sqrt{ }$ & $\sqrt{ }$ & $\sqrt{ }$ & $\sqrt{ }$ & $\sqrt{ }$ & $\sqrt{ }$ & $\sqrt{ }$ \\
\hline $\begin{array}{l}\text { Russula atroglauca } \\
\text { Einhell. }\end{array}$ & -- & -- & $\sqrt{ }$ & -- & -- & -- & $\sqrt{ }$ & -- & -- & -- & -- & $\sqrt{ }$ & $\sqrt{ }$ & $\sqrt{ }$ & -- \\
\hline Russula aurata Fr. & -- & $\sqrt{ }$ & $\sqrt{ }$ & -- & -- & -- & -- & -- & -- & -- & - & -- & -- & -- & -- \\
\hline Russula azurea Bres. & -- & -- & -- & -- & -- & $\sqrt{ }$ & $\sqrt{ }$ & $\sqrt{ }$ & $\sqrt{ }$ & $\sqrt{ }$ & $\sqrt{ }$ & $\sqrt{ }$ & $\sqrt{ }$ & $\sqrt{ }$ & $\sqrt{ }$ \\
\hline
\end{tabular}


Russula odorata

Romagn.

Russula

cremeoavellanea

Singer

Russula cyanoxantha

(Schaeff.) Fr.

Russula delica Fr.

Russula exalbicans

(Pers.) Melzer \&

Zvára

Russula foetens Pers.

Russula font-queri

Singer

Russula globispora (J.

Blum) Bon

Russula maculata

Quél.

Russula acrifolia Rom agn.

Russula olivobrunnea

Ruots. \& Vauras

Russula pallidospora

J. Blum ex Romagn.

Russula pelargonia

Niolle

Russula persicina 
Krombh.

Russula puellula

$\begin{array}{llllllllllllllllllllllllllllll}\text { Ebbesen, F.H. Møller } & -- & -- & -- & -- & -- & \sqrt{ } & -- & -- & \sqrt{ } & \sqrt{ } & \sqrt{ } & \sqrt{ } & \sqrt{ } & -- & \sqrt{ }\end{array}$

\& Jul. Schäff.

Russula romellii

Maire

Russula subrubescens

Murrill

Russula velenovskyi

Melzer \& Zvára

Russula vitellina Gray

Russula xerampelina

(Schaeff.) Fr.

Russula sp 1

Russula sp 2

Russula sp 3

Russula sp 4

Russula sp 5

Russula sp 6

Russula sp 7

Russula sp 8

Russula sp 9

Russula sp 10

Russula sp 11 


\begin{tabular}{|c|c|c|c|c|c|c|c|c|c|c|c|c|c|c|c|}
\hline Russula sp 12 & -- & -- & -- & -- & -- & -- & -- & -- & $\sqrt{ }$ & -- & -- & $\sqrt{ }$ & -- & $\sqrt{ }$ & -- \\
\hline Russula sp 13 & -- & -- & -- & -- & -- & -- & -- & -- & $\sqrt{ }$ & -- & -- & -- & -- & $\sqrt{ }$ & -- \\
\hline Russula sp 14 & -- & -- & -- & -- & -- & -- & -- & -- & -- & -- & $\sqrt{ }$ & -- & -- & -- & -- \\
\hline Russula sp 15 & -- & -- & -- & -- & -- & -- & -- & -- & -- & -- & -- & -- & -- & -- & $\sqrt{ }$ \\
\hline Russula sp 16 & -- & -- & -- & -- & -- & -- & -- & -- & $\sqrt{ }$ & -- & -- & -- & -- & $\sqrt{ }$ & -- \\
\hline Russula sp 17 & -- & $\sqrt{ }$ & -- & -- & -- & -- & -- & -- & -- & -- & -- & -- & -- & -- & -- \\
\hline Russula sp 18 & -- & $\sqrt{ }$ & $\sqrt{ }$ & -- & -- & -- & -- & -- & -- & -- & -- & -- & -- & -- & -- \\
\hline Russula sp 19 & -- & $\sqrt{ }$ & -- & -- & -- & -- & -- & -- & -- & -- & -- & -- & -- & -- & -- \\
\hline Russula sp 20 & -- & -- & $\sqrt{ }$ & -- & -- & -- & -- & -- & -- & -- & -- & -- & -- & -- & -- \\
\hline Russula sp 21 & -- & -- & $\sqrt{ }$ & -- & -- & -- & -- & -- & -- & -- & -- & -- & -- & -- & -- \\
\hline Russula sp 22 & -- & -- & $\sqrt{ }$ & -- & -- & -- & -- & -- & -- & -- & -- & -- & -- & -- & -- \\
\hline Russula sp 23 & -- & -- & $\sqrt{ }$ & -- & -- & -- & -- & -- & -- & -- & -- & -- & -- & -- & -- \\
\hline Russula sp 24 & -- & $\sqrt{ }$ & -- & -- & -- & -- & -- & -- & -- & -- & -- & -- & -- & -- & -- \\
\hline
\end{tabular}




\section{Table 2 (on next page)}

Menhinick richness index, Shannon diversity index and Pielou's evenness index of the Russulaceae fungi on the aboveground associated with Quercus mongolica from June to October.

${ }^{a} n=5$. The values are the means \pm standard errors. Different letters refer to significant differences between the months according to Tukey's test at $p<0.05$. 
2

3 Table 2

4 Menhinick richness index, Shannon diversity index and Pielou's evenness index of the Russulaceae fungi on 5 the aboveground associated with Quercus mongolica from June to October.

\begin{tabular}{cccccc}
\hline & August & July & September & October & June \\
& & & & \\
\hline Menhinick $^{\mathrm{a}}$ & $3.11 \pm 0.00 \mathrm{a}$ & $2.04 \pm 0.01 \mathrm{ab}$ & $1.00 \pm 0.58 \mathrm{~b}$ & $0.00+0.00 \mathrm{~b}$ & $0.00+0.00 \mathrm{~b}$ \\
& & & & & \\
Shannon $^{\mathrm{a}}$ & $2.75 \pm 0.01 \mathrm{a}$ & $2.44 \pm 0.01 \mathrm{~b}$ & $0.00+0.00 \mathrm{c}$ & $0.00+0.00 \mathrm{c}$ & $0.00+0.00 \mathrm{c}$ \\
& & & & & \\
Pielou's evenness $^{\mathrm{a}}$ & $0.87 \pm 0.01 \mathrm{~b}$ & $0.92 \pm 0.01 \mathrm{a}$ & $0.00+0.00 \mathrm{c}$ & $0.00+0.00 \mathrm{c}$ & $0.00+0.00 \mathrm{c}$ \\
\hline
\end{tabular}

6

7

8

$9{ }^{a} \mathrm{n}=5$. The values are the means \pm standard errors. Different letters refer to significant differences between the 10 months according to Tukey's test at $p<0.05$.

11 


\section{Table 3(on next page)}

Chao richness index and Shannon diversity index of the Russulaceae fungal communities in roots and soils from June to October.

${ }^{a} \mathrm{n}=5$. The values are the means \pm standard errors. Different letters refer to significant differences between months according to Tukey's test at $p<0.05$.

${ }^{\mathrm{b}}$ The values are the Chao mean \pm Chao standard deviation (analytical) in each month. 


\section{Table 3}

2 Chao richness index and Shannon diversity index of the Russulaceae fungal communities in roots and soils 3 from June to October.

4

5

6

Root Shannon $2.24 \pm 0.06$ a $2.28 \pm 0.06$ a $1.47 \pm 0.05$ b $1.50 \pm 0.04$ b $2.22 \pm 0.02$ a

7

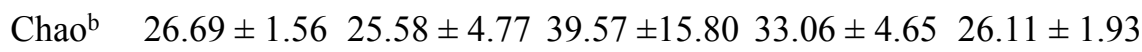

8

9

Soil Shannon ${ }^{\mathrm{a}} 2.71 \pm 0.02$ a $2.18 \pm 0.02$ b $2.75 \pm 0.02$ a $2.12 \pm 0.03$ b $2.20 \pm 0.02$ b

10

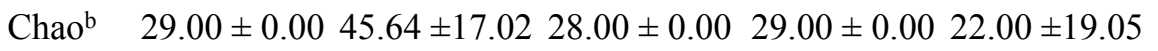

11

12

13

14

15

${ }^{a} \mathrm{n}=5$. The values are the means \pm standard errors. Different letters refer to significant differences between months according to Tukey's test at $p<0.05$.

17 ${ }^{\mathrm{b}}$ The values are the Chao mean \pm Chao standard deviation (analytical) in each month.

18

19 


\section{Table 4 (on next page)}

The difference of Shannon index between the aboveground and root and between the aboveground and soil, respectively, in July and August.

Tukey's test at $p<0.05$. 


\section{Table 4}

2 The difference of Shannon index between the aboveground and root and between the aboveground and soil,

3 respectively, in July and August.

4

\begin{tabular}{|c|c|c|c|}
\hline & & Root & Soil \\
\hline July & sporocarps & 0.048 & 0.001 \\
\hline
\end{tabular}

6

$\begin{array}{llll}\text { August } & \text { sporocarps } & 0 & 1\end{array}$

7

8 Tukey's test at $p<0.05$.

9 


\section{Table 5 (on next page)}

Correlation between the alpha diversity index of the Russulaceae fungi sporocarps on aboveground and environmental variables in a Quercus mongolica forest.

Significance level: $0.01<*<0.05$. 


\section{Table 5}

2 Correlation between the alpha diversity index of the Russulaceae fungi sporocarps on aboveground and

3 environmental variables in a Quercus mongolica forest.

4

\begin{tabular}{llllllllll}
\hline Temp & MR & RH & pH & N & K & SOM & SM & P
\end{tabular}

5

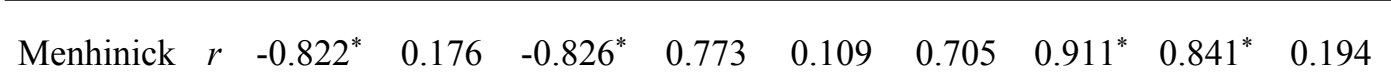

6

$$
\begin{array}{llllllllll}
p & 0.045 & 0.739 & 0.043 & 0.071 & 0.838 & 0.118 & 0.012 & 0.036 & 0.712
\end{array}
$$

7

8

$\begin{array}{llllllllll}p & 0.793 & 0.032 & 0.772 & 0.679 & 0.916 & 0.685 & 0.989 & 0.797 & 0.736\end{array}$

$\begin{array}{lllllllllll}\text { Pielou } & r & 0.753 & 0.613 & 0.781 & -0.753 & -0.104 & -0.756 & -0.78 & -0.788 & -0.339\end{array}$

9

$$
\begin{array}{llllllllll}
p & 0.084 & 0.196 & 0.067 & 0.084 & 0.845 & 0.082 & 0.067 & 0.063 & 0.511
\end{array}
$$

10

11

12

13 Significance level: $0.01<*<0.05$.

14 


\section{Table 6(on next page)}

Description of the functional groups on the genera significantly associated with the Russulaceae fungi from belowground.

In the root, Y1: Russula, U1: Cortinarius, U2: Exophiala, U3: Herpotrichia; Z1: Lactarius, V1: Inocybe, V2: Nectria, V3: Dictyochaeta. In soil, Y2: Russula, W1: Lachnum, W2: Ilyonectria, W3: Cadophora; Z2: Lactarius, X1: Preussia, X2: Cortinarius, X3: Herpotrichia. 


\section{Table 6}

2 Description of the functional groups on the genera significantly associated with the Russulaceae fungi from 3 belowground.

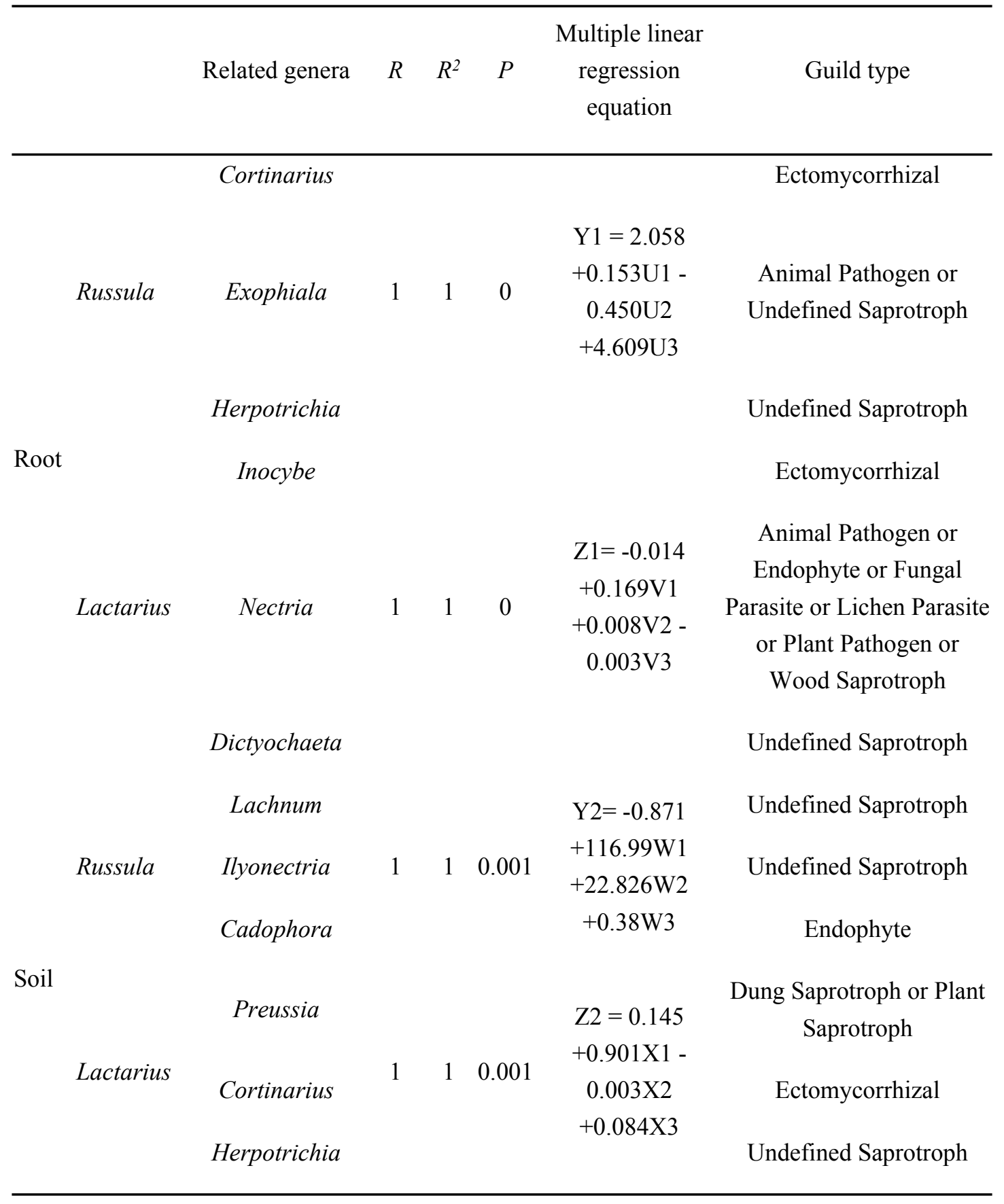

4

5 In the root, Y1: Russula, U1: Cortinarius, U2: Exophiala, U3: Herpotrichia; Z1: Lactarius, V1:

6 Inocybe, V2: Nectria, V3: Dictyochaeta. In soil, Y2: Russula, W1: Lachnum, W2: Ilyonectria, 
7 W3: Cadophora; Z2: Lactarius, X1: Preussia, X2: Cortinarius, X3: Herpotrichia.

8

Peer] reviewing PDF | (2019:09:41576:1:2:NEW 9 Dec 2019) 


\section{Table 7 (on next page)}

Months of the abiotic factors associated with the Russulaceae fungi. 


\section{Table 7}

2 Months of the abiotic factors associated with the Russulaceae fungi.

3

4

\begin{tabular}{cccccccccc}
\hline Month & $\begin{array}{c}\mathrm{MR} \\
(\mathrm{mm})\end{array}$ & $\begin{array}{c}\mathrm{RH} \\
(\%)\end{array}$ & $\begin{array}{c}\text { Temp } \\
\left({ }^{\circ} \mathrm{C}\right)\end{array}$ & $\mathrm{SM}(\%)$ & $\mathrm{pH}$ & $\begin{array}{c}\mathrm{N} \\
\left(\mathrm{mg} \cdot \mathrm{kg}^{-1}\right)\end{array}$ & $\begin{array}{c}\mathrm{K}\left(\mathrm{mg} \cdot \mathrm{kg}^{-}\right. \\
\mathrm{l})\end{array}$ & $\begin{array}{c}\mathrm{SOM}(\%) \\
\left(\mathrm{mg} \cdot \mathrm{kg}^{-1}\right)\end{array}$ \\
\hline July & 251.60 & 87.00 & 20.80 & 57.08 & 6.05 & 321.67 & 523.10 & 15.69 & 34.90 \\
August & 145.40 & 86.00 & 17.30 & 61.61 & 6.14 & 321.35 & 610.58 & 17.67 & 32.32 \\
\hline
\end{tabular}

